\title{
THE RELATION OF THE SUBSTRATUM TO THE METAMORPHOSIS OF OPHELIA LARVAE
}

\author{
By Douglas P. Wilson, M.Sc., F.R.P.S. \\ Zoologist at the Plymouth Laboratory
}

(Plates XV-XVII)

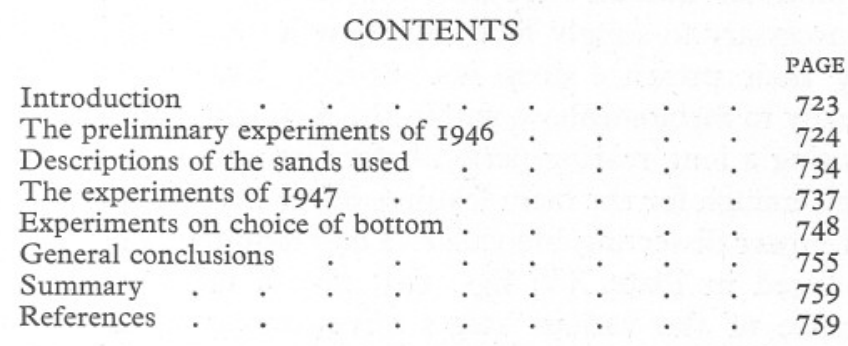

INTRODUCTION

It has previously been shown for the pelagic larvae of more than one species of polychaete (Wilson, 1932, 1937; Day \& Wilson, 1934) that there is a period of time varying from a few days to several weeks during which the fully developed larva will metamorphose whenever it comes into contact with a substratum suitable for adult life. During this period the larva is able to test the varying types of bottom over which the currents carry it and to select and metamorphose in the particular kind of mud, sand or gravel that forms the normal habitat of the species. The natural processes of development thus do not force metamorphosis to take place at some definite critical stage in the growth of the larva. It is the external environment, or some feature of it, which stimulates the larva to change from an active free-swimming organism to a sluggish semi-sedentary worm buried in the bottom.

The power of selection is likely to be most strongly developed in species restricted to particular kinds of bottom soil. It would obviously not be so important to a species capable of inhabiting a wide range of bottoms, but would be an invaluable factor in aiding the survival of those confined to one special kind of sand or mud. Ophelia bicornis Savigny is such a species; it appears to be confined to loose, clean sand in which few other animals are present. It is abundant in certain parts of the Exe estuary, notably on the Bullhill Bank and the Polesands, where it has flourished since at least the beginning of the century, Allen \& Todd (1902) having found it in large numbers in the same locality nearly fifty years ago. For a chart of the locality reference should be made to their paper. The development of this species is described separately (Wilson, I948). In this paper are recorded the results 
of experiments designed to test the assumption that the larvae would exhibit a marked preference for sand from the adult habitat and would not readily undergo metamorphosis if other sands, or none at all, were supplied. This having proved true, later experiments were devoted to an attempt to discover how the larvae distinguish between various kinds of sand and to show that actual selection can take place, to some extent at least, in the unnatural confines of a glass dish. Ophelia larvae proved very suitable on the whole for experiments of this nature. Apart from their strongly marked reaction to various kinds of bottom they live well crowded in small dishes, and it appears unnecessary to supply food, for though some flagellates were added occasionally their presence does not seem to have made any difference. They are ready to metamorphose within the fortnight, a great advantage over larvae requiring a long rearing period before being ready to settle, and they are just large enough for the main features of the metamorphosis to be visible with a high-power dissecting binocular. The photomicrographs by electronic flash reproduced in Plate XV, figs. I-3, give a fairly good impression of the appearance of the various stages alive among sand grains from the Bullhill Bank. Ideally the larvae should be just a little larger, as they are undoubtedly difficult to find in most sands until they move. When sand is first removed from an experimental dish, and strewn underwater in a glass tray for searching, the metamorphosed young worms curl up and tend to keep still for a time. After some minutes they begin to crawl about again, and it is then that they are most easily found. Moreover, being smaller than many of the sand grains they are often concealed from view unless active. Their chief drawback is their power of adhesion, strongly developed in the later stages, which causes them to stick to the surface film, to glass, to cotton fragments (Plate XV, fig. 4) and other debris, and to one another by the mucus they secrete. At first they pull themselves free, but later on are unable to do so in the quiet water of a dish. The practical difficulty of supplying some substitute for the strong currents of their natural environment was not overcome in these experiments.

Worms were collected and fertilizations made as have already been described in another paper (Wilson, 1948). The methods adopted will be described under each experiment.

\section{The Preliminary Experiments of I946}

\section{Experiment I}

The results of an early experiment to compare the reactions of larvae in the presence of sand to larvae kept in clean dishes are shown in Table I. Two finger bowls, each containing numerous larvae from the same fertilization, were stood side by side so that as far as possible each was under the same conditions of lighting and temperature. To one bowl sand from the Polesands was added. The water in the bowls was unfiltered outside sea water, and 
it contained numbers of small diatoms, flagellates, etc. Little attention was paid to this preliminary experiment, because during the period that it was running the main embryological features of the development were being worked out, but the bowls were examined from time to time. It will be seen that larvae in the bowl with sand soon metamorphosed, whilst the great majority in the clean bowl did not do so. On 6 May the newly metamorphosed worms were crawling actively among the sand grains and seemed particularly healthy in comparison with the unmetamorphosed larvae and the few partially metamorphosed ones sticking to the bottom of the clean bowl. Conditions were similar on 13 May. Owing to pressure of other work these bowls were not disturbed again until 6 June, when it was found, with some astonishment, that the clean bowl still contained many unmetamorphosed larvae which, although stuck to the bottom with the anal papillae, swam when released.

\section{TABLE I. EXPERIMENT I}

(Begun 27. iv. 46 with larvae from a fertilization of I8. iv. 46.)

\begin{tabular}{|c|c|c|c|}
\hline & Clean bowl & $\begin{array}{l}\text { Dish containing } \\
\text { Polesand sand }\end{array}$ & Polesand sand \\
\hline 29. iv. 46 & Unmet. & - & ? Meting \\
\hline 6. v. 46 & $\begin{array}{l}\text { Majority unmet.; a few have } \\
\text { lost their prototrochal cilia }\end{array}$ & - & Majority metd \\
\hline I3. v. 46 & Majority unmet. & - & All metd \\
\hline 6. vi. 46 & $\begin{array}{l}\text { Some dead, but many un- } \\
\text { met. with strong proto- } \\
\text { trochs and often telotrochs. } \\
\text { Some larvae removed to } \\
\text { small dish containing sand }\end{array}$ & $\begin{array}{l}\text { Unmet. larvae introduced } \\
\text { from clean bowl }\end{array}$ & All metd \\
\hline I2. vi. 46 & $\begin{array}{l}\text { Many dead but living larvae } \\
\text { still with prototrochs, tele- } \\
\text { trochs and sometimes apical } \\
\text { tufts }\end{array}$ & $\begin{array}{l}\text { Sand searched; found } 2 \text { I } \\
\text { metd or meting, } 2 \text { unmet. } \\
\text { and } 2 \text { dead larvae }\end{array}$ & Not examined \\
\hline 5. vii. 46 & All dead & All dead & All dead \\
\hline
\end{tabular}

The following contractions are used in tables: metd, metamorphosed; meting, metamorphosing; unmet. unmetamorphosed; $c$. approximately; $d$, dead.

There was considerable algal growth on the sides and bottom of the bowl testifying to its age, but the bowl was unusually healthy and there were no ciliates visible in spite of the remains of several dead larvae. The sand bowl, on the other hand, was much infected with ciliates, but in the sand there were numerous young worms with long bristles, although still only at the threesetiger stage beyond which none has so far been reared. On this date an uncounted number of unmetamorphosed larvae were removed from the clean bowl and placed in a smaller dish containing Polesand sand. Six days later a search of this sand revealed that the majority had metamorphosed or were metamorphosing, whilst in the clean bowl, in spite of many further deaths, there were still larvae with prototrochs, telotrochs and sometimes apical tufts. Thus, 7 weeks after fertilization, larvae were still able to swim and to 
metamorphose, given suitable sand conditions; this, although other larvae from the same fertilization had completely metamorphosed some 5 weeks previously.

There is no doubt that the larvae fertilized on I8 April 1946 were one of the healthiest cultures I have had. They were much used in working out the details of the development and in making the drawings published in the previous paper (Wilson, 1948). I have not since been able to keep larvae unmetamorphosed and healthy over such a long period of time, but quite early in the work it was noted that the healthier the culture the more definite are the reactions of the larvae to the presence or absence of suitable sand. Unhealthy larvae are much more liable to start metamorphosing without sand; particularly do they lose cilia and become unable to swim. This fertilization of I8 April was, on I3 May, the subject of a special note contrasting its health most favourably with other cultures in being at that time. This fertilization was made from worms collected at Exmouth on I3 April and sent to Plymouth by rail.

\section{Experiment 2}

Sixty swimming larvae 9 days old were placed in each of three dishes, respectively the clean control, a dish with sand from the Bullhill Bank, and a dish with flocculent mud from Salcombe (Table II). On examination 5 days later only fifty-two larvae were found in the clean control, but fifty of them were unmetamorphosed. In the Bullhill sand twenty-four metamorphosed young worms were found together with seven unmetamorphosed and two dead, one of the latter possibly metamorphosed. In the mud, in spite of a careful search, protracted over $3 \mathrm{hr}$., only five larvae were accounted for and only one of them was metamorphosed. Three days later the remaining larvae in the clean control were still unmetamorphosed.

TABLE II. EXPERIMENT 2

(Begun 29. v: 46 with larvae from a fertilization of 20. v. 46.)

$\begin{array}{clll}\text { 29. v. } 46 & \text { Clean dish } & \text { Bullhill sand } & \text { Salcombe mud } \\ \text { 3. vi. } 46 & \text { Unmet. } 60 & \text { Unmet. 60 } & \text { Unmet. 60 } \\ & \text { Metd I } & \text { Metd 24 } & \text { Metd I } \\ \text { Unmet. 50, } d \mathrm{I} & \text { Unmet. 7, } d 2 & \text { Meting 2 } \\ \text { 6. vi. } 46 & \text { All unmet. } & \text { Not examined } & \text { Unmet. I, } d \text { I } \\ \text { Not examined }\end{array}$

The discrepancy between the numbers of larvae put into each dish and the number found is easily explained. Nine-days-old larvae stick readily to any solid object, and very likely some of them were lost in the pipette and never got into the dishes at all. Too much sand and mud were used in this experiment, making it extremely difficult to carry out a complete search. Larvae are especially easily concealed in the mud, but, nevertheless, it seems highly probable that in the mud the majority were smothered and died. 
The difficulty experienced in transferring known numbers of larvae from one dish to another, and more especially in finding them all again in even very small quantities of sand or mud, made it necessary to adopt a somewhat easier technique. It was thought that if a comparatively large, though unknown, number of larvae were put into each experimental dish, it would be sufficient for the purpose of the experiment to recover only a fraction of them. Any marked difference in reaction to various types of bottom deposits would be shown by the proportions of metamorphosed to metamorphosing and unmetamorphosed larvae among those recovered by random sampling. It would not be necessary to search the whole of the sands or mud; this would result in a great saving of time and labour. As it turned out even this method demanded a great expenditure of time and effort, and it was physically impossible for one person to do more than was done by working long hours whilst the experiments were in progress. The results, however, were on the whole satisfactory for the purpose in hand, and marked differences in settlement reactions to the various soils were clearly shown.

\section{Experiment 3}

This was the first of the experiments in which tests were made of a number of different types of bottom deposits. Small glass dishes approximately $3 \mathrm{~cm}$. in diameter were thinly strewn with the deposits to be tested. The deposits were sterilized by boiling and well washed in filtered sea water before being used. The dishes were put all together on black paper on a large enamel tray, covered with glass covers and placed in a comparatively cool place. A considerable but unknown number of larvae were put into each. The larvae were 8 days old and were showing the first signs of settling. The experiment is summarized in Table III.

On 2I June, 8 days after the start of the experiment, none of the larvae in the clean dish had metamorphosed. They were attached by their anal papillae to the bottom of the dish, to the surface film, or to cotton fragments or other debris, sometimes in clusters. Almost all had prototrochs and telotrochs, but one or two were seen which had lost the cilia. When water was squirted at them with a pipette the larvae came off the bottom and swam about for a time. In contrast with this was the condition in the dish containing Bullhill sand (Pl. XVI, fig. I); here, except for a few unmetamorphosed larvae on the surface film, the sand was alive with metamorphosed young worms with long bristles. In a few minutes thirty were counted, but there were many more. One unmetamorphosed and two metamorphosing larvae were also found. It was quite evident that the great majority of the larvae in this dish had metamorphosed, almost the only unmetamorphosed ones being stuck to the surface film. On the other hand, the dish with a few grains of Bullhill sand sprinkled over the bottom contained no metamorphosed larvae, though about 10 \% had lost or were losing the prototrochal cilia, generally the first stage in meta- 
morphosis. The fine 'Gritty' sand (Pl. XVII, fig, 3 ) consisting of particles of an angular nature with sharp edges and corners had many larvae in or on it, but not one had metamorphosed, although sixteen had lost their prototrochal cilia and may have been beginning to metamorphose. A hundred unmetamorphosed larvae were actually counted and there were still more left in the sand. In the shell gravel a small proportion had metamorphosed and rather more were metamorphosing though a large majority were unmetamorphosed. The mud, as usual, was difficult to search, but in $2 \mathrm{hr}$. forty-seven unmetamorphosed larvae were seen. Four of these had lost the cilia of the prototroch, but it is doubtful whether they were actually metamorphosing. Not a single metamorphosed worm was found in this dish.

\section{TABLE III. EXPERIMENT 3}

(Begun I3. vi. 46 with larvae from a fertilization of 5. vi. 46.)

\begin{tabular}{|c|c|c|c|c|}
\hline \multirow[b]{2}{*}{ Clean dish } & \multicolumn{3}{|c|}{ 21. vi. 46} & 2. vii. 46 \\
\hline & Unmet. c. I5O & & - & $\begin{array}{l}\text { Many dead. A few living } \\
\text { unmet. }\end{array}$ \\
\hline Bullhill sand & (a) Unmet. Io & (c) & $\begin{array}{l}\text { Metd } 30 \\
\text { Meting } 2 \\
\text { Unmet. I }\end{array}$ & $\begin{array}{l}\text { Good number metd, healthy. } \\
\text { I or } 2 \text { unmet. }\end{array}$ \\
\hline $\begin{array}{l}\text { Bullhill sand (a few } \\
\text { grains only) }\end{array}$ & (a) Unmet. 25 & (c) & $\begin{array}{l}\text { Metd o } \\
\text { Possibly meting ro } \\
\text { Unmet. } 80-90\end{array}$ & $\begin{array}{l}\text { Mainly dead or dying, unmet. } \\
\text { A few may be partially } \\
\text { metd }\end{array}$ \\
\hline Fine 'Gritty' sand & (a) Unmet. I2 & (c) & $\begin{array}{l}\text { Metd o } \\
\text { Meting I6 } \\
\text { Unmet. IOo }\end{array}$ & $\begin{array}{l}\text { None properly metd, but a } \\
\text { fair number possibly meting }\end{array}$ \\
\hline Shell gravel & (a) Unmet. 6 & (c) & $\begin{array}{l}\text { Metd } 4 \\
\text { Meting } 29 \\
\text { Unmet. } 60\end{array}$ & $\begin{array}{l}\text { Several metd, a few meting } \\
\text { and a few unmet. Some } \\
\text { dead. }\end{array}$ \\
\hline Salcombe mud & (a) Unmet. 4 & (c) & $\begin{array}{l}\text { Metd o } \\
\text { Meting o } \\
\text { Unmet. } 47\end{array}$ & None seen \\
\hline
\end{tabular}

(a) on surface film; (c) in gravel, sand or mud.

After the examination on 2I June all the counted larvae and deposits were returned to their respective dishes. On 2 July a further, but briefer, examination was made. The results are summarized in Table III and do not need a detailed explanation.

This experiment shows clearly that larvae will settle readily in Bullhill Bank sand and there metamorphose at an age when they will scarcely do so at all in other deposits. The fact that larvae on the surface film only a little distance above the sand do not metamorphose at the same time as those in it seems to indicate that physical contact with the sand is the main stimulus to metamorphosis. A few thinly scattered and isolated grains of this sand are less effective in bringing about metamorphosis than a deposit of the coarser particles of shell gravel. 


\section{Experiment 4}

In order to investigate more fully the relation between the physical character of the bottom deposit and metamorphosis a bigger experiment along similar lines to that of Exp. 3 was undertaken. Except for the omission of mud the same types of bottom were repeated with, in addition, several new natural and artificial deposits. Before the actual results set out in Table IV are considered these need some explanation.

Penrhyn Bay sand (Pl. XVII, fig. I) came from a shore in north Wales where, to the best of my belief, Ophelia is absent. It is similar in many respects to Bullhill Bank sand (P1. XVI, fig. I), the grains generally being well rounded, though on the whole smaller (see analysis, p. 736), and it contains a considerably higher portion of shell fragments. Eddystone shell gravel consists mainly of relatively large and worn shell fragments; they were well washed so as to be much cleaner than they are in nature. The fine 'Gritty' sand has already been described. The other bottoms were more artificial in nature: Bullhill sand mixed with a roughly equal proportion by volume of well-washed Carborundum grit No. I20 (P1. XVII, fig. 4); the Carborundum grit alone; Bullhill sand cemented in a single close layer to the bottom of a dish with Murrayite cement, so that each grain was immovably fastened by its base though in contact with neighbouring grains; fragments of broken No. I coverglass; glass wool in a fairly thick layer on the bottom of the dish; fine capillary tubing broken up and in a heap; similarly with coarser tubing; finally, lattices made of criss-crossed strips of No. I cover-glass and rather thicker glass. The strips were crossed in layers at right angles and cemented together with Murrayite cement at the points of contact. The larvae could thus get in between the horizontal layers of glass separated by a distance equal to the thickness of the glass used. These thicknesses were: for No. I cover-glass about I80 $\mu$; for the thin glass about $330 \mu$. The larvae used in this experiment came from a very successful fertilization made on I July. Almost 100\% of the eggs developed and the larvae were very healthy. The experiment was started on 6 July at a time when all the larvae were swimming freely in their finger bowls. They were at a stage when the first two setigers have bristles, but those of the third setiger have not appeared. A large but unknown number of larvae were put into each of the small experimental dishes of approximately $3 \mathrm{~cm}$. internal diameter. As before, these were all covered and stood together on black paper in a cool place not too strongly illuminated.

Two days later the dishes were examined as closely as possible without removing the deposits from the bottom. In almost every dish the great majority of the larvae were swimming actively, but in the dish with Bullhill sand few were swimming, and it was seen that the majority were in the sand metamorphosing or metamorphosed, the latter crawling actively among the sand grains. They already had the characteristic long bristles which none of 


\section{TABle IV. EXPERIMENT 4}

(Begun 6. vii. 46 with larvae from a fertilization of I. vii. 46.)

Clean dish

Bullhill sand

Penrhyn Bay sand

Eddystone shell gravel

Fine 'Gritty' sand

Bullhill sand and

Carborundum

Carborundum

Bullhill sand cemented in a single layer

Broken cover-glass

Glass wool

Broken fine capillary glass tubing

Broken coarse capillary glass tubing

Lattice of No. I coverglass

$$
\text { II. vii. } 46
$$

Almost all swimming. Some swimming, majority sticking on surface film and bottom, all A few stuck to bottom unmet.

A few swimming, but (a) Metd I

majority in sand

meting and metd

(a) Unmet. 35

A few in sand unmet.

All swimming

All swimming

Majority swimming.

A few in mixture, one metd

Majority swimming. None metd

I or 2 swimming, others on surface film or in sand

Majority swimming. Some among fragments. A few metd I or 2 swimming. Majority in wool unmet.

Majority swimming.

Some amid tubing unmet.

$\begin{array}{ll}\text { (a) Unmet. I2 } & \text { (b) } \mathrm{I} 2\end{array}$

Majority swimming Some in lattice unmet.

Lattice of thin microslide Majority swimming,
some in lattice unmet.

$$
\text { Meting I }
$$$$
\text { Unmet. I5 }
$$

(b) I5 at least

(a) Unmet. 50

(b) A good number

(a) Unmet. 6

(b) 97 at least

(a) Unmet. 28

(b) 16

$\begin{array}{ll}\text { (a) Unmet.c. } 60 & \text { (b) } 50+\end{array}$

(a) Unmet. 7

(b) 4

(a) Unmet. Io

(b) None

(a) Unmet. 32

(b) 2 or 3

(a) Unmet. 7

(b) None

(b) 2 or 3

(c) Metd $50+$ Meting o

Unmet. 4 $\begin{array}{ll}\text { (c) Metd 20, } d_{2} & \text { All living fairly } \\ \text { Meting } \mathrm{II}_{3}, d_{3} & \text { healthy }\end{array}$ Unmet. $43, d 4$

(c) Metd I Unmet. many

(c) Metd 5 Meting 7 Unmet. 32

(c) Metd 3 Meting 6 Unmet. $67+$

(c) Many unmet.

(c) Metd I Meting o
Unmet. 56

c) Metd 8 Meting 2 Unmet. I 16

c) Metd 4 Meting I Unmet. $68, d 2$

(c) Unmet. c. 100

Very healthy

Mainly very healthy healthy

Very healthy

Healthy

Very healthy

Very healthy

Healthy

Healthy

Living larvae healthy

(a) Unmet. c. 60

(c) Unmet. c. Ioo

Healthy

(c) All unmet. on Healthy bottom of dish or in and about lattice

(c) All unmet. on Healthy bottom of dish or . in and about lattice

(a) on surface film; (b) swimming freely; (c) in bottom deposit. 
the swimming larvae possessed. Even in the cemented Bullhill sand the larvae were down amid the grains, though here only one larva was seen to be probably metamorphosing, all the others were unmetamorphosed. The glass-wool had attracted, or trapped, many but none was metamorphosed. Amid the broken cover-glass, however, there were a few metamorphosed larvae with long bristles crawling about, though the majority still swam. The difference between the Bullhill sand and the Penrhyn Bay sand was striking.

On the fifth day of the experiment each dish was carefully searched, the various deposits being removed for this purpose. The results are summarized in Table IV, but it should be noted that except for the clean dish, and the various deposits of glass where it was relatively easy to find all the larvae present, a complete count or examination of every larva in the dish could not for certain be made. However, in the half-hour and more devoted to each dish few larvae can have escaped observation. In the Table a + after a figure means that more larvae were seen than were actually counted.

In every dish larvae were trapped on the surface film, sometimes in quite large numbers. These must be ignored when comparing the effect of the different types of bottom, though a word must be said concerning the single metamorphosed and the metamorphosing larva on the film above the Bullhill sand. It is quite probable that these had been carried from the sand below by air bubbles such as are formed when gases come out of solution during a rise in temperature, or in photosynthesis. Indeed, on II July there were also grains of sand on the film; these had not been there previously and must have been raised in some such way. There were similar sand grains in the Penrhyn Bay dish and Carborundum grains on the surface film in the two dishes containing that substance. Indeed, the appearance of sand grains on the surface film is a not unusual feature during the course of an experiment, and the presence, therefore, of metamorphosed larvae on the film does not necessarily imply that they metamorphosed in that position. In this experiment there were large numbers of metamorphosed larvae in the Bullhill sand on 6 July, and as since that date sand grains had appeared on the film it is not surprising to find that one or two of these larvae had been carried up with them.

The results as set out in Table IV largely speak for themselves. Once again in the Bullhill sand dish the larvae are far ahead of all others in metamorphosis and in the development of long bristles. In the unmetamorphosed larvae the bristles were much shorter and those on the third setiger were on this same day only just protruding from the seta sacs-the young metamorphosed worms had third setiger bristles many times this length, and those of the first and second setiger were likewise elongated over those of their unmetamorphosed relatives. Penrhyn Bay sand had by this fifth day induced a fair proportion to metamorphose, but was definitely well behind Bullhill sand. A few metamorphosed worms with their long bristles were found in some of the other dishes, but the proportions are much smaller still. It is 
striking how the addition of Carborundum grit and the cementing of the grains in an immovable single layer each upsets the metamorphosis-inducing properties of the Bullhill sand.

\section{Experiment 5}

The results of the preceding experiments having indicated that the stimulus to metamorphose is probably given by the purely physical nature of the bottom deposit, a further experiment was devised to rule out, as far as possible, the chance that the most effective bottom deposits (Bullhill sand and Penrhyn Bay sand) contained some substance that by slowly dissolving out was perceived by the larvae in a chemical manner. These two sands were therefore treated in various ways. In the acid treatment strong hydrochloric acid was followed by sulphuric bichromate solution such as is used in cleaning glassware, and finally well washed. Sand was also twice boiled, treated with absolute alcohol, and heated to redness for over Io min. Sands thus treated were compared with the natural sands which were merely washed in fresh and sea water, without sterilization by boiling as is usual in most experiments. In these latter sands a few living nematodes were seen. Unsterilized Penrhyn Bay sand in which some adult Ophelia had been kept was also used to see if the adults could impart something to the sand which would make it more attractive to the larvae. A living adult Ophelia was also put into an otherwise clean dish. The larvae used were from the same fertilization as those of Exp. 4, but it was 3 days later that this experiment was set up and by that time many of the larvae in the culture bowls were already attached by their anal papillae to the bottom. However, some were still swimming and it was these swimming larvae which were used.

The results of this experiment are shown in Table V. It was not possible to search all the sands exhaustively though the major portion of that in each dish was examined for $20 \mathrm{~min}$. or so. No significant differences are to be noted between any of the results, and it seems evident that previous treatment of the sands in the manner described had no observable effect on the reactions of the larvae towards them. At the end of the experiment the larvae and young worms were several days older than at the conclusion of Exp. 4; this and the fact that their metamorphosis had already been delayed several days before the experiment was set up probably accounts for their often poorer condition. Also in setting up this experiment larvae were removed from two separate culture bowls (both, of course, of the same age), and it may be that those in one bowl were by that time not as healthy as those in the other, with corresponding results in the dishes they were put into. At any rate, there is no obvious correlation of the state of health with the kind of sand used or with its previous treatment. To the extent that the larvae were relatively old when the experiment started and that two separate culture bowls instead of one were used the experiment is unsatisfactory, but the main purpose for which it was devised seems to have been attained. It again shows that the physical size 
TABLE V. EXPERIMENT 5

(Begun 9. vii. 46 with larvae from a fertilization of I. vii. 46.)

\begin{tabular}{|c|c|c|c|c|c|c|}
\hline Clean dish & (a) & Unmet. I I & (b) c. I2 & (c) & $\begin{array}{l}\text { Metd } 7 \\
\text { Meting } 5 \\
\text { Unmet. 6I, } d 7\end{array}$ & $\begin{array}{l}\text { Fairly healthy. Metd worms } \\
\text { lethargic }\end{array}$ \\
\hline $\begin{array}{l}\text { Bullhill sand washed in } \\
\text { fresh water and sea water }\end{array}$ & (a) & None & (b) None & (c) & $\begin{array}{l}\text { Metd 3I } \\
\text { Meting o } \\
\text { Unmet. o, } d \text { I }\end{array}$ & Healthy \\
\hline $\begin{array}{l}\text { Penrhyn Bay sand washed } \\
\text { in fresh water and sea } \\
\text { water }\end{array}$ & (a) & Unmet. 3 & (b) None & (c) & $\begin{array}{l}\text { Metd 3I } \\
\text { Meting I } \\
\text { Unmet. o, } d 22\end{array}$ & Fairly healthy \\
\hline Bullhill sand acid treated & (a) & None & (b) None & (c) & $\begin{array}{l}\text { Metd } 33 \\
\text { Meting } 5 \\
\text { Unmet. 6, } d_{3}\end{array}$ & Healthy \\
\hline Bullhill sand twice boiled & (a) & None & (b) None & (c) & $\begin{array}{l}\text { Metd } 23 \\
\text { Meting } 6 \\
\text { Unmet. 2, d } 6\end{array}$ & Unhealthy \\
\hline $\begin{array}{l}\text { Bullhill sand heated to } \\
\text { redness }\end{array}$ & (a) & None & (b) None & & $\begin{array}{l}\text { Metd } 36 \\
\text { Meting } 3 \\
\text { Unmet. 9, } d \text { I2 }\end{array}$ & $\begin{array}{l}\text { Majority of metd healthy, all } \\
\text { the unmet. unhealthy }\end{array}$ \\
\hline $\begin{array}{l}\text { Bullhill sand washed in } \\
\text { absolute alcohol }\end{array}$ & (a) & None & (b) None & (c) & $\begin{array}{l}\text { Metd 24, } \mathrm{I}_{\mathrm{I}} \\
\text { Meting } 3 \\
\text { Unmet. } 2, d_{4}\end{array}$ & Health poor \\
\hline $\begin{array}{l}\text { Penrhyn Bay sand acid } \\
\text { treated }\end{array}$ & (a) & ? Meting 2 & (b) None & (c) & $\begin{array}{l}\text { Metd } 25 \\
\text { Meting } 5 \\
\text { Unmet. I, } d 6\end{array}$ & Moderately healthy \\
\hline $\begin{array}{l}\text { Penrhyn Bay sand after } \\
\text { contact with Ophelia }\end{array}$ & (a) & None & (b) None & (c) & $\begin{array}{l}\text { Metd } 2 \mathrm{I}, d_{\mathrm{I}} \\
\text { Meting } \mathrm{I}, d_{\mathrm{I}} \\
\text { Unmet. } \mathrm{o}, d_{3}\end{array}$ & Fairly healthy \\
\hline $\begin{array}{l}\text { Clean dish with adult } \\
\text { Ophelia }\end{array}$ & & 一 & - & & All unmet.; mainly dead & - \\
\hline
\end{tabular}

I5. vii. 46 and I6. vii. 46

3
0
0
0
3
0
0
0
0
0
0
0
0
0
0
0
0
0
0
T
5
5
5


and shape of the deposit particles rather than the presence of any dissolving chemical substance is most probably the factor inducing metamorphosis, although chemical stimulus is not entirely ruled out by it.

\section{DESCRIPTIONS OF THE SANDS USED}

By the conclusion of Exp. 5 the breeding season for 1946 was virtually over and no more really healthy fertilizations were obtained that year. In the following year good fertilizations were not obtained until early in June, the breeding season having been delayed perhaps by the unusually severe weather of the previous winter; it was very cold from about the middle of January to the end of February 1947. The new series of experiments was planned to obtain more precise information about the physical characters of sand in which larvae would readily metamorphose and to determine, if possible, whether anything in the nature of a soluble substance played any part. With this end in view various sands were chosen and graded well in advance of the breeding season. The grading was done by drying the sands and passing them through simple sieves made from selected grades of new bolting silk tightly held between close-fitting metal sleeves. The silks selected were those in stock in the laboratory and had $26,40,60,86$, I00 and 200 meshes to the inch. Each sample of sand was washed in fresh water and thoroughly dried; it was then passed in succession through the various silks from the coarsest to the finest, so that eventually its component particles were separated out into a series of grades of nearly uniform particle size. The separated grades were kept in clean screw-stoppered jars ready for use. Each grade is designated according to the silks used to separate it. Thus grade 40-60 mesh means sand which has passed forty meshes to the inch but has been retained by sixty.

The sands treated in this way were as follows. In order to have an independent opinion as to their composition I asked Dr A. G. Lowndes to examine and describe a specimen of each, which he very kindly consented to do.

(I) Bullhill Bank sand from an area where adult Ophelia were collected in quantity. It is a very clean sand (Pl. XVI, fig. I), 'homogeneous in size; large grains rounded; mineral chiefly quartz, tourmaline in small quantities; small amount of shell; ferruginous material. The 40-60-mesh grains are distinctly rounded, few fragmented, but in the 86-100-mesh sizes (P1. XVI, fig. 2) more angular fragments are present, although the majority of the grains are still rounded (A.G.L.).'

The proportions by weight (per Ioo g.) of the various grades were:

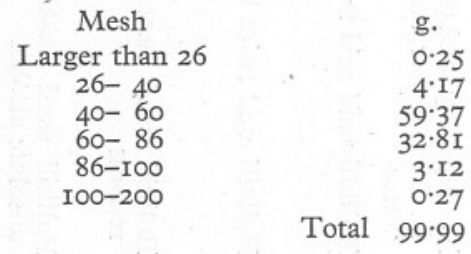


(2) Exmouth high-water sand. This was collected from just below the promenade at Exmouth. It was well above ordinary high-water mark and certainly contained no living Ophelia. It was very clean and of the same or very similar mineral content, but contained a higher proportion of small pebbles: 'quite large rounded pebbles, some of which contain crystals of tourmaline; quartzite pebbles and rounded crystals of quartz; many small angular quartz fragments; fragments of shell; calcite; many pebbles of local rock (shale) up to $5 \mathrm{~mm}$. The 40-60-mesh grains are distinctly rounded but in the 86-100-mesh sizes the majority are angular, though a fair proportion are rounded (A.G.L.),'

The proportions by weight were:

$\begin{array}{cr}\text { Mesh } & \text { g. } \\ \text { Larger than } 26 & 46 \cdot 00 \\ 26-40 & 9 \cdot 00 \\ 40-60 & 22 \cdot 80 \\ 60-86 & 13 \cdot 00 \\ 86-100 & 8 \cdot 00 \\ \text { 100-200 } & 0 \cdot 64 \\ & \text { Total } 99.44\end{array}$

(3) Salthouse Lake sand. This sand was collected during a brief excursion across the channel separating the Salthouse Lake area from the Bullhill Bank. It was about a quarter of a mile from the main collecting ground for Ophelia, but at a slightly lower tidal level. In character the shore where it was taken was quite different from the Bullhill Bank, the sand being firmer and finer with a little admixture of mud. Arenicola marina was abundant, with Tellina tenuis and a general and quite rich sand fauna. Casual digging did not turn up any Ophelia, though in a nearby region this species was present, in much smaller numbers than on the Bullhill Bank (personal communication from Mr N. A. Holme).

An analysis of this small sample (about $25 \mathrm{~g}$.) gave the following composition:

$\begin{array}{cc}\text { Mesh } & \text { g. } \\ \text { Larger than } 26 & \text { Nothing } \\ 26-40 & 0 \cdot 12 \\ 40-60 & \mathrm{I} \cdot 40 \\ 60-86 & 2 \mathrm{I} \cdot 60 \\ 86-100 & 53 \cdot 40 \\ \text { 100-200 } & 22 \cdot 08 \\ & \text { Total } 98 \cdot 60\end{array}$

It will be seen from the figures that this sand was much finer than that of the Bullhill Bank. When thrown into water a slight cloudiness was left behind after the sand had settled, showing the presence of very fine particles. A few grains passed the $200 \mathrm{mesh}$, but the amount was very small indeed. This sand (Pl. XVI, fig. 3) was 'homogeneous, medium grained, consisting of grains of quartz chiefly, angular not rounded; grains of tourmaline fairly abundant; small fragments of shell (A.G.L.)'. The mineral composition appeared to be very similar to the Bullhill Bank and Exmouth high-water sands. 
(4) Kames Bay sand. This was sand from Millport, Isle of Cumbrae. It is finer (Pl. XVI, fig. 4) than that of the Bullhill Bank and not quite so clean. 'A clear homogeneous sand impregnated with iron; grains angular with very little rounding; small amount of shell fragments and echinoid spines; no tourmaline; a little zircon (A.G.L.).' The mineral content was not quite the same. The noteworthy feature of this sand is that it was inhabited by an allied species of Ophelia, the much smaller $O$. cluthensis McGuire, and the sand used came from a place where these worms were very numerous. The proportions of the various grades by weight were:

\begin{tabular}{|c|c|c|}
\hline $\begin{array}{c}\text { Mesh } \\
\text { Larger than } 26 \\
26-40 \\
40-60 \\
60-86 \\
86-100 \\
\text { 100-200 }\end{array}$ & & $\begin{array}{r}\text { g. } \\
0.32 \\
\text { I.93 } \\
24.51 \\
52.90 \\
19.35 \\
0.96\end{array}$ \\
\hline & & 99.9 \\
\hline
\end{tabular}

(5) Penrhyn Bay sand. As already mentioned, this came from a shore in north Wales where Ophelia, although not extensively looked for, is almost certainly absent. It is a sand (Pl. XVII, fig. I), 'homogeneous in size, fairly coarse; quartz and shell fragments; grains angular and rounded in about equal proportion. No tourmaline (A.G.L.)'. There are more shell fragments in this sand than in that from the Bullhill Bank. The proportions by weight of its various grades showed that it was a finer sand than that of the Bullhill Bank. These proportions were:

$\begin{array}{cc}\text { Mesh } & \text { g. } \\ \text { Larger than 26 } & 0 \cdot 23 \\ 26-40 & 2 \cdot 12 \\ 40-60 & 36 \cdot 32 \\ 60-86 & 48 \cdot 58 \\ 86-100 & 10 \cdot 37 \\ \text { I00-200 } & 2 \cdot 35 \\ & \text { Total } \\ & 99 \cdot 97\end{array}$

(6) Polzeath sand. A sand (P1. XVII, fig. 2) consisting of a very high proportion of broken shell fragments. 'At least $50 \%$ shell fragments, all polished with rounded corners; angular quartz fragments; grains of local shale and grits; very few small grains (A.G.L.).' The finer mesh sizes contained a higher proportion of angular fragments than the natural sand or the coarser mesh sizes. The proportions of the various grades by weight were:

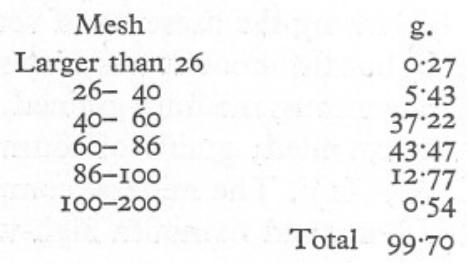


From this it will be seen that it was rather similar in grade to sand from the Bullhill Bank. In all other features it was a sand of quite a different character.

(7) 'Gritty' sand. This was a sand of uncertain origin; it probably came from a dredging in deep water. It was found in an unlabelled bottle in the laboratory and seemed very suitable for use as a contrast to the other sands. It consisted of sharply angular mineral particles mixed with broken and rather sharp fragments of mollusc shells, Echinus spines and plates, etc. 'Rather coarse but homogeneous with a large number of shell fragments, many quartz grains and mica shale; very angular (A.G.L.).' This sand is referred to as 'Gritty' sand, and has already been mentioned by that name when describing the 1946 experiments. In that year, however, the sand was sifted under water to remove the larger fragments, sufficient of the smaller particles being removed with a pipette to form the 'fine gritty sand' (P1. XVII, fig. 3) of those experiments. The quantity so used was less than half a gram, and hence was not very suitable for grading by the rather rough method used. However, a careful estimation gave the following result, worked out to Ioo g. for comparison with other sands:

Mesh
Larger than 26
$26-40$
$40-60$
$60-86$
$86-100$
$100-200$

g.
Nothing
Nothing
$1 \cdot 6$
$5 \cdot 4$
$27 \cdot 3$
$65 \cdot 5$
Total $99 \cdot 8$

Nothing passed the $200-$ mesh silk. It will be seen that this artificially selected sand consisted mainly of very small particles.

For the 1947 experiments the 'Gritty' sand in its original state as found in the bottle was graded and several of the grades were used as such, as will be noted under the various experiments. The ungraded sand was not so used, so that an analysis of it is unnecessary.

(8) B.D.H. sand, purified by acid. This is a laboratory reagent. Two grades supplied by the British Drug Houses Ltd. were used, 30-40 mesh and 60-80 mesh. By mixing these and regrading through the silks, sands of coarser, finer and intermediate grades were obtained. In composition it consisted of 'large rounded grains of quartz and small angular grains; very little ferruginous material; grains containing sillimanite and natiolite (A.G.L.)'. The sand was pale cream in colour.

\section{THE ExPERIMENTS OF I947}

\section{Experiment 6}

This is the first of the experiments in which graded sands were used. Various grades of Bullhill Bank sand were compared with natural Bullhill Bank, graded B.D.H. acid purified, and a coarse and fine grade of 'Gritty' sand. A clean dish served as a control. 
TABle VI. EXPERIMENT 6

(Begun 13. vi. 47 with larvae from a fertilization of 9. vi. 47.)

\begin{tabular}{|c|c|c|c|c|c|c|}
\hline \multirow[b]{2}{*}{ Clean dish } & \multicolumn{4}{|c|}{ 23. vi. 47 and 24. vi. 47} & \multicolumn{2}{|c|}{ 27. vi. 47} \\
\hline & (a) Unmet. 40 & (b) A few & $\begin{array}{l}\text { (c) Unmet. a large } \\
\text { number }\end{array}$ & Healthy & $\begin{array}{l}\text { None metd though } \\
\text { some prototrochal } \\
\text { cilia lost. One may } \\
\text { be meting }\end{array}$ & Moderately healthy \\
\hline Bullhill Bank sand & (a) Unmet. I2 & (b) One & $\begin{array}{l}\text { (c) Metd } 5 \\
\text { Meting } 4 \\
\text { Unmet. but pos- } \\
\text { sibly meting } 12\end{array}$ & Healthy & $\begin{array}{l}\text { (c) Metd I3 } \\
\text { Meting I } \\
\text { Possibly meting } 2 \\
\text { Unmet. } 3\end{array}$ & $\begin{array}{l}\text { Metd fairly healthy, } \\
\text { others unhealthy }\end{array}$ \\
\hline $\begin{array}{l}\text { Bullhill Bank, } \\
\text { 26-40 mesh }\end{array}$ & (a) Unmet. c. 60 & (b) None & $\begin{array}{l}\text { (c) Metd } 6 \\
\text { Meting } 9 \\
\text { Unmet. but pos- } \\
\text { sibly meting } 8\end{array}$ & Healthy & $\begin{array}{l}\text { (c) Metd I5 } \\
\text { Meting I } \\
\text { Unmet. } 3\end{array}$ & Mainly unhealthy \\
\hline $\begin{array}{l}\text { Bullhill Bank, } \\
\text { 40-60 mesh }\end{array}$ & (a) Unmet. c. 30 & (b) None & $\begin{array}{l}\text { (c) Metd } 6 \\
\text { Meting } 5 \\
\text { Unmet., some pos- } \\
\text { sibly meting } 7\end{array}$ & Healthy & $\begin{array}{l}\text { (c) Metd 2I } \\
\text { Meting } 6 \\
\text { Unmet. I }\end{array}$ & $\begin{array}{l}\text { Some fairly healthy, } \\
\text { others unhealthy }\end{array}$ \\
\hline $\begin{array}{l}\text { Bullhill Bank, } \\
60-86 \text { mesh }\end{array}$ & (a) Unmet. c. 35 & (b) None & $\begin{array}{l}\text { (c) Metd } 7 \\
\text { Meting } 6 \\
\text { Unmet., some pos- } \\
\text { sibly meting } 9\end{array}$ & Healthy & $\begin{array}{l}\text { (c) Metd I4 } \\
\text { Meting } 6 \\
\text { Unmet. } 3\end{array}$ & $\begin{array}{l}\text { Some fairly healthy, } \\
\text { others unhealthy }\end{array}$ \\
\hline $\begin{array}{l}\text { Bullhill Bank, } \\
\text { 86-roo mesh }\end{array}$ & (a) Unmet. $70-80$ & (b) Two & $\begin{array}{l}\text { (c) Metd } 6 \\
\text { Meting Io } \\
\text { Unmet. } 42\end{array}$ & Healthy & $\begin{array}{l}\text { (c) Metd } 3 \\
\text { Meting } 6 \\
\text { Possibly meting } 5 \\
\text { Unmet. I4 }\end{array}$ & Mainly unhealthy \\
\hline
\end{tabular}


B.D.H. sand, acid purified, 26-40 mesh

B.D.H. sand, acid purified, 40-60 mesh

B.D.H. sand, acid purified, 60-86 mesh

B.D.H. sand, acid purified, 86-roo mesh

'Gritty' sand, 40-60 mesh

'Gritty' sand, 86-100 mesh (a) Unmet. Io

(a) Unmet. $\mathrm{I}_{5}$

(a) Unmet. I4

(a) Unmet. 8 Possibly meting I

(b) None

b) None

Meting 4

Unmet. 9

(c) Metdo

Meting 2

Unmet. I6

Abnormal unmet. 2

(a) Unmet. I6

(b) None

(c) Metd o

Meting 2

Possibly meting Io

Unmet. I5

(a) Unmet. 16

(b) None

(c) Metd 2

Meting 2

Possibly meting 2

Unmet. I7, $d$ I
Unhealthy Not examined

Unhealthy Not examined

Unhealthy

Not examined

Unhealthy Not examined

Fairly healthy

(c) Metd 6

Meting 4

Possibly meting 2

Unmet. 3

(c) Metd I

Meting I

Possibly meting 4

Unmet. 5

(a) on surface film; (b) swimming freely; (c) in portion of sand or on bottom. 
The same volume of sand (a level saltspoonful) was used in each instance, and each quantity was separately boiled, well rinsed in tap water and then given several washings in filtered sea water from outside the breakwater ('outside water'). All dishes were acid-cleaned and well washed. Larvae used were from a batch of eggs naturally shed and fertilized on 9 June 1947. These eggs had been transferred from circulation water to outside water and gave rise to a strong healthy culture of larvae. A small quantity of autotrophic flagellates from laboratory cultures was added to supply food if needed.

To make sure of providing the larvae with opportunities to metamorphose as soon as they were ready to do so, the experiment was set up early at a time when they were not showing any tendency to attach themselves by the anal papillae and the third setiger had not developed bristles. This was probably a mistake, for as it turned out many of the larvae got caught on the surface film, or stuck themselves thereto, before they were ready to metamorphose. Moreover, by starting the experiment early the dishes had to stand without change of water for a longer period than would otherwise have been necessary, and this may have been partly responsible for the poor health of the larvae at the end of the experiment.

In Table VI the results are set out. The larvae on the surface films were removed from the influence of the sands and must therefore be ignored in considering the results. Metamorphosis was seen to have begun in some of the sand pots on 2I June, that is, 8 days after the larvae had first been put in the dishes. A careful examination of each pot was started on 23 June and finished the next day. In every instance all larvae on the surface film were carefully removed with a pipette before a little of the sand was taken out and searched. Searching took about I5 min. or longer; in the 'Gritty' sands the larvae were particularly hard to see, and with each of these the time of searching was extended to about an hour. The 86-100 grade of Bullhill Bank sand was searched for half an hour. In the semi-transparent colourless grains of the B.D.H. sand the larvae were clearly visible, and easily found. The sands which had been removed and searched and the larvae found in them were not returned to the dishes but were discarded, as were all the larvae on the surface films.

It is obvious that only the numerical proportions between unmetamorphosed, metamorphosing and metamorphosed larvae are significant, and this must be borne in mind when comparing dish with dish. In numerous instances it was very difficult to distinguish between larvae which were unmetamorphosed and those which had perhaps begun to metamorphose. Where necessary this is indicated in the table. It will be seen that all the Bullhill Bank sands except the 86-Ioo grade show very similar results, but the latter seems quite definitely to have a small proportion of its larvae metamorphosed or metamorphosing. Some of the larvae were stuck together in clusters of several individuals, but all were healthy, as, indeed, were all those 
in Bullhill sand. On the other hand, all the larvae in the B.D.H. pots were markedly unhealthy, though here again the finest grade used had a higher proportion of unmetamorphosed larvae than did the others. In both coarse and fine 'Gritty' sands only a small proportion had metamorphosed or were metamorphosing; the health of these dishes was fairly good.

On 27 June a final examination was made. In the clean dish the larvae were still unmetamorphosed with some not very active cilia on their prototrochs, and they were moderately healthy. In all the Bullhill sands except the finest grade metamorphosed larvae greatly preponderated over unmetamorphosed, while the reverse was true for the 86-1oo grade. The results for the 'Gritty' sands were not good, but they do show something similar when coarse and fine grades are compared, though here the coarser grade does not appear to be as effective in producing metamorphosis as the corresponding grade of Bullhill sand. The B.D.H. sands were unhealthy on the first examination on 24 June and therefore were not re-examined on 27 June.

\section{Experiment 7}

This experiment was similar in conception to the last, only here various mesh sizes of Exmouth high-water sand were tested. This sand was the nearest sort to the Bullhill sand in which it was certain that adult Ophelia had not been living. In addition, other sands of quite different types were also tested. The same preliminary sterilizations and washings of the sand were carried out as for Exp. 6 and larvae from the same fertilization were used. The experiment was set up 2 days later than Exp. 6, but even so an unduly large proportion of the larvae attached themselves to, and thereby became trapped on, the surface film. The dishes were first looked at ro days after the experiment began, and the examination of the various dishes took 2 days to complete. The results are shown in Table VII. All the larvae and sands removed from the dishes on 25 and 26 June for counting were discarded and not returned to the experiment. Great care was taken to remove all larvae on the surface film before disturbing the sand. A little filtered sea water was added to several of the dishes to make up for that lost by removal of these larvae. Some of the dishes were examined again on 4 July.

Once again the larvae metamorphosed more readily in the Bullhill sand than in any of the other sorts and, moreover, were, on the whole, considerably healthier than in the other dishes. The various grades of the Exmouth highwater sand gave unexpectedly poor results; it was thought that the 40-60- and 60-86-mesh sizes would have induced a high proportion of larvae to metamorphose. Grains of these sizes form the bulk of the Bullhill sand, and there is little difference in geological character between the latter and the sand from high-water mark a mile or so away. The high-water grains tend to be a little more angular, but except for the smallest sizes this is not very noticeable. The larvae in the dish containing 40-60-mesh size high-water sand were not really 
TABle VII. EXPERIMENT 7

Begun 15. vi. 47 with larvae from a fertilization of 9. vi. 47.)

\section{Clean dish I}

Clean dish II

Bullhill Bank sand

Exmouth high water

Exmouth high water, 26-40 mesh

Exmouth high wate

Exmouth high water, 60-86 mesh

Exmouth high water,

Exmouth high water,

100-200 mesh

Salthouse Lake sand

Kames Bay sand

Kames Bay recombined i Buns of Bullhill sand

Polzeath, 40-60 mesh

Polzeath, 60-86 mesh

Polzeath recombined in pro-

'Gritty' sand recombined in
25. vi. 47 (a) Unmet. 33

(c) Unmet. c. 70

(a) Unmet. c. 70

(a) Unmet. c. 60

(a) Unmet. c. 100

(a) Unmet. 70

(a) Unmet. c, 60

(a) Unmet. c. 50

(a) Unmet. c. 70 Meting $\mathrm{I}$

$$
\text { - }
$$
$\begin{array}{ll}\text { (a) Unmet. c. } 80 & \text { (c) Metd o } \\ \text { Meting 2 }\end{array}$ Meting 2
Possibly meting 4
Unmet. I I

(c) Metd I4 Meting 5

(c) Metd 3 Unmet. 4I

(c) Metd I Unmet. I5 Metd 5

(c) Metd I Meting 3
Unmet. I6

(c) Metd 2

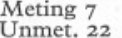

(c) Metd $\circ$ Meting 6
Unmet. 40$$
\text { - }
$$

-

(c) Ist count 2nd count Meting I2 IO
Healthy

-

Very
healthy
Healthy
Healthy
$\begin{gathered}\text { Moderatel } \\ \text { healthy }\end{gathered}$
Healthy
Quite
healthy
$\begin{gathered}\text { Fairly } \\ \text { healthy } \\ -\end{gathered}$
-
(a) Possibly meting $\mathrm{I}$ Unmet. c. 35

26. vi. 4

$\overbrace{-}^{\text {vi. } 47}$

-

$$
-
$$$$
-
$$$$
\text { - }
$$$$
\text { - }
$$

(c) Metd o
Meting $\mathbf{r}$
Unmet.

(c) Metd 5

Meting 4
Probably meting

Probably meting
Early meting 9

(c) Metd o
Meting I

Meting I
Unmet. 5

Possibly meting
Unmet. $70-80$

$70-80$
-
Very
healthy

-

$-$

$-$

-

(a) Unmet. c. 30

- (a) Unmet. c. 30

Moderately

healthy
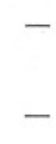

- (a) Unmet. c. 80

- (a) Unmet. c. 15 (a) Unmet. c. 25

(a) Unmet. 50-60

(c) Metd o Meting O
Unsibly meting I
Unmet. 20

(c) Metd o Meting I
Possibly meting Unssibly meting

(c) Metd o

Meting I

$\mathrm{I}$ or 2 may be Unmet. 24

(c) Metd 2

Meting 4
Possibly meting 5
Unmet, I5 ossibly meting
Unmet. $18, d \mathrm{I}$

Metd 3

ossibly meting 7

$$
\text { of sand. }
$$

(a) on surface film; (c) on bottom or in portion of sand.
4. vii. 47

c) Majority umet, but 3 Health poor possibly meting

All unmet.

(c) Metd 15
Meting 2

Moderately

Fairly

Unmet. 0

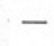

Moderately healthy

Unhealthy

Moderately

healthy

$$
\text { - }
$$$$
-
$$

Health

poor

(c) Metd 5

Unmet.

Moderately

healthy

(c) Metd 17

Meting I
Unmet. o
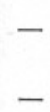

-

-

$$
\text { - }
$$

poor

Fairly

Very

healthy

Metd 5

Meting I

Fairly

Moderately

healthy

(c) Metd ro

Meting ro
Unmet. 0

Moderately

Healthy

Moderately
healthy 
healthy, and it may be that some infection in this dish affected the result. The larvae in the 60-86-mesh dish were fairly healthy, however, and yet showed an even more marked reluctance to metamorphose. In the other sands metamorphosis was delayed compared with the Bullhill sand, although in most of them larvae did eventually succeed in metamorphosing. The vast majority of the larvae in the two clean dishes were still unmetamorphosed at the end of the experiment.

A few words should be inserted here on the condition of the unmetamorphosed larvae. On 25 and 26 June those on the surface film of all dishes had strong prototrochal cilia and almost certainly apical tufts and telotrochs as well. With the dissecting binocular used in this work it was not very easy to see cilia other than those forming the prototroch which when present was always clearly visible. On the same dates the unmetamorphosed larvae in the various sands also nearly always had good prototrochs and could generally swim well when disturbed, but in a number the ciliation was rather irregular and a few had lost most of the cilia, though otherwise retaining the prototrochal tissue. By 4 July few of the unmetamorphosed larvae, even those on the surface film, retained any of their cilia, although the other tissues of the prototroch were clearly visible. The general health conditions were, however, poor, and this may have been partly responsible for this loss of tissue. On this date it was, indeed, difficult to classify the larvae properly at all, and some of those put down as metamorphosing may possibly have been fully metamorphosed but imperfectly formed.

Some of the unmetamorphosed larvae on the surface films were stuck together by their anal papillae in little clusters and some surrounded cotton fragments, though a great many were attached to the film singly. In the sands, particularly the two finest grades from Exmouth high water, there were also little clusters of larvae; these were sometimes visible on the surface of the sand before the latter was disturbed.

\section{Experiment 8}

The tests of the Exmouth high-water sand made in the last experiment not having proved very satisfactory on account of the unhealthy state of several of the dishes, it was decided to try the various grades again and at the same time to include a graded series of Bullhill sand. In addition to these, the four grades 26-40, 40-60, 60-86 and 86-100 mesh of both Bullhill and Exmouth high-water sands were recombined in the correct proportions by weight to resemble Bullhill Bank sand. These recombined sands lacked only particles larger than 26 mesh and smaller than Ioo mesh, both of which, as shown on p. 734 , are present in the natural Bullhill sand in very small proportion only. To one of the recombined Exmouth high-water sands a little Bullhill Bank natural sand was added. Some further tests with Carborundum grit No. I2O (Pl. XVII, fig. 4) were also included, but in the mixture with Bullhill natural sand only about a third part was Carborundum - a smaller proportion than in 
Exp. 4. The grit did not mix uniformly with the sand, and there were patches of the latter almost free from it.

On the whole this experiment was much healthier than the preceding two and there was never any difficulty in deciding to which category a larva belonged, as was rather often so in Exps. 6 and 7. The unmetamorphosed were strongly ciliated, short in body and without long bristles, the metamorphosing were distinctly elongating with narrow and interrupted prototrochs which still retained some cilia, and the bristles were elongating. The metamorphosed had no less distinctly lost all cilia, were elongated and had long bristles, especially on the third setiger. Individuals rarely departed from these standards ${ }^{1}$ which were not always so closely followed in other experiments. This variation in health of different experiments was probably to a large extent due to variation in the state of maturity of the eggs and sperms at fertilization.

The main results of Exp. 8 are set out in Table VIII. The experiment was started on 9 July with 6-days-old larvae which were swimming strongly, though occasionally using the anal papillae to attach themselves to the sides of the glass bowl in which they were kept. Attachment was always only temporary; attached larvae easily released themselves and swam away again. They were strongly negatively phototropic; there were no bristles on the third setiger. The sands and dishes were cleaned and sterilized as described for Exp. 6; a new feature was a black paper collar around each dish so that light came only from above, and the dishes were stood on black paper. It was hoped by this means to drive the negatively phototropic larvae away from the surface film. Unfortunately, many larvae were again trapped, perhaps at night but also certainly by day as well. On II July larvae on the surface film were released by dropping freshly filtered outside sea water on to them from a pipette, but they were soon back again. On that day several fully metamorphosed larvae were observed in the sands of some of the dishes. It was intended to make a count on I3 and I4 July, but this could not be done until I5 and I6 July.

All larvae on the surface films were carefully removed before the sands were disturbed. There were always large numbers of these except in one or two instances where the dish was so full of water that the watch-glass dust-cover dipped below the surface and so reduced the area of water-air interface. In future experiments it may be possible to devise some such means of avoiding this particular trouble with the larvae. Before the dishes were disturbed care was always taken to note whether any larvae were swimming freely and whether any could be seen on the surface of the sand. It was impossible within the time available to search all the sands; a portion only was removed from each dish for this purpose.

It had been noted in the previous experiment that larvae often tended to stick together in clusters, especially unmetamorphosed larviae on unsuitable

1 The general appearance of these stages is shown in Plate XV, figs. I-3, which are of larvae from an experiment in 1948 . 
sands. In this experiment therefore clusters are recorded as such, the number of larvae forming each cluster being noted. Such clusters could often be observed lying on the surface of the sand before any of the latter was removed for examination.

Some of the results of this experiment are clear and definite. Larvae in the clean dish and those on the surface films of all the other dishes were still unmetamorphosed some time after many in contact with sand had undergone the critical change. The ungraded, or natural sand from the Bullhill Bank was rarely equalled by any of the graded sands in its property of stimulating larvae to metamorphose. Of the graded sands the 40-60 mesh from Exmouth high water gave a result comparable with that of the Bullhill Bank natural, and there was a marked reduction in efficiency of coarser and finer grades. In the graded Bullhill Bank sand of the 40-60-mesh size the larvae did not seem to be quite as healthy as was usual in this experiment, and this probably affected the result. None the less this grade did on the whole yield a higher proportion of metamorphosed worms than the others, though less than could reasonably be expected. In the two finest grades of both sorts of sand only a very few larvae metamorphosed; in these dishes the great majority of the larvae were unchanged and were often stuck together in clusters of several individuals. The sands recombined from four sifted grades were variable in their effect, though some of the Exmouth recombined sands were almost as efficient as the Bullhill Bank natural. Carborundum grit again had a marked effect, changing the properties of the Bullhill Bank natural sand to which it was added, and in itself proved an unsuitable medium for larval settlement.

It will be noted that there is a difference in result between the two dishes of Bullhill Bank natural sand. In the first dish twenty healthy metamorphosed worms were counted in $5 \mathrm{~min}$. and many more seen, whereas in the second dish Io min. searching yielded only nineteen metamorphosed and about half as many unmetamorphosed larvae. It is possible that fewer larvae had originally been put into this dish than into the first one. It was noticed that the larvae and worms in the second dish were not as healthy as in the first dish, and this may have been a prime cause in influencing the result. These differences in health between dish and dish may be due to chance bacterial infection; it is impracticable to conduct experiments of this nature under bacteriologically sterile conditions. The small number of larvae on the surface film of the second dish was due to the bottom of the watch-glass cover dipping into the water so as almost to obliterate the air-water interface normally present.

The experiment was completed on I6 July, but the clean dish was kept and examined again on 23 July, the larvae by then being 20 days old. Some of the larvae had metamorphosed, both on the surface film and on the bottom, but were imperfectly formed, and some were metamorphosing. Other larvae were still unmetamorphosed, but had lost most or all of the prototrochal cilia. 


\section{TABle VIII. EXPeriment 8}

(Begun 9. vii. 47 with larvae from a fertilization of 3. vii. 47.)

I5. vii. 47

\begin{tabular}{|c|c|c|c|c|}
\hline Clean dish & (a) All unmet. & - & (c) All unmet. & Very healthy \\
\hline $\begin{array}{l}\text { Bullhill Bank sand, } \\
\text { dish No. I }\end{array}$ & (a) Unmet. c. 150 & (b) None & 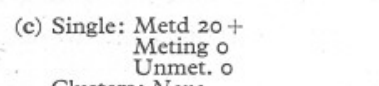 & Very healthy \\
\hline $\begin{array}{l}\text { Bullhill Bank sand, } \\
\text { dish No. } 2\end{array}$ & (a) Unmet., a few & (b) None & $\begin{array}{l}\text { Clusters: None } \\
\text { (c) Single: Metd I9 } \\
\text { Meting 4 } \\
\text { Unmet. 9, } d_{2} \\
\text { Clusters: Unmet. 2 }\end{array}$ & Fairly healthy \\
\hline $\begin{array}{l}\text { Bullhill Bank, } \\
\text { 26-40 mesh }\end{array}$ & $\begin{array}{l}\text { (a) Unmet., large } \\
\text { number }\end{array}$ & (b) None & $\begin{array}{c}\text { (c) Single: } \begin{array}{l}\text { Metd ro } \\
\text { Meting } 8 \\
\text { Unmet. } 9\end{array} \\
\text { Clusters: Unmet. } 4,5,6\end{array}$ & Healthy \\
\hline $\begin{array}{l}\text { Bullhill Bank, } \\
40-60 \text { mesh }\end{array}$ & (a) Unmet., many & (b) None & $\begin{array}{l}\text { Clusters: Unmet. 4, 5, } 6 \\
\text { (c) Single: Metd I2 } \\
\text { Meting } 4 \\
\text { Unmet. } 6\end{array}$ & $\begin{array}{l}\text { Some unhealthy, } \\
\text { others moderately } \\
\text { healthy }\end{array}$ \\
\hline $\begin{array}{l}\text { Bullhill Bank, } \\
60-86 \text { mesh }\end{array}$ & $\begin{array}{l}\text { (a) Unmet., large } \\
\text { number }\end{array}$ & (b) Several & $\begin{aligned} & \text { Clusters : Unmet. 4, 5, } \\
& \text { (c) Single: } \text { Metd II } \\
& \text { Meting 7 } \\
& \text { Unmet. 9 } \\
& \text { Clusters: Meting 2 } \\
& \text { Unmet. 4, 8, 3, 4, 7 }\end{aligned}$ & Moderately healthy \\
\hline $\begin{array}{l}\text { Bullhill Bank, } \\
\text { 86-100 mesh }\end{array}$ & $\begin{array}{l}\text { (a) Unmet., large } \\
\text { number }\end{array}$ & (b) A few & 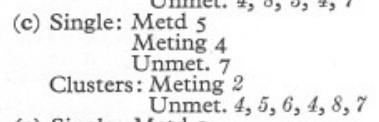 & Very healthy \\
\hline $\begin{array}{l}\text { Bullhill Bank, } \\
\text { IO0-200 mesh }\end{array}$ & (a) Unmet. $150-200$ & (b) None & $\begin{aligned} & \text { (c) Single: } \text { Metd o } \\
& \text { Meting o } \\
& \text { Unmet. } 8 \\
& \text { Clusters: Unmet. } 4\end{aligned}$ & Healthy \\
\hline $\begin{array}{l}\text { Bullhill Bank, four } \\
\text { grades recom- } \\
\text { bined, dish No. I }\end{array}$ & $\begin{array}{l}\text { (a) Unmet., large } \\
\text { number }\end{array}$ & (b) Several & $\begin{array}{l}\text { Clusters: Unmet. } 4 \\
\text { (c) Single: } \text { Metd 12 } \\
\text { Meting 6 } 6 \\
\text { Unmet. ro } \\
\text { Clusters: Meting 3 } \\
\text { Unmet. } 2\end{array}$ & Healthy \\
\hline $\begin{array}{l}\text { Bullhill Bank, four } \\
\text { grades recom- } \\
\text { bined, dish No. } 2\end{array}$ & $\begin{array}{l}\text { (a) Unmet., large } \\
\text { number }\end{array}$ & (b) Several & 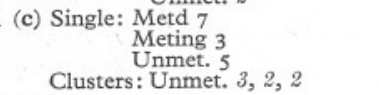 & Moderately healthy \\
\hline $\begin{array}{l}\text { Bullhill Bank and } \\
\text { Carborundum }\end{array}$ & - & - & - & - \\
\hline $\begin{array}{l}\text { Carborundum grit } \\
\text { No. } 120\end{array}$ & - & - & - & - \\
\hline $\begin{array}{l}\text { Exmouth high water, } \\
\text { 26-40 mesh }\end{array}$ & $\begin{array}{l}\text { (a) Unmet., large } \\
\text { number }\end{array}$ & (b) Several & 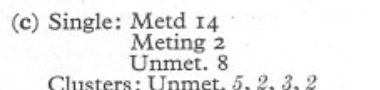 & Healthy \\
\hline $\begin{array}{l}\text { Exmouth high water, } \\
40-60 \text { mesh }\end{array}$ & (a) Unmet., many & (b) None & $\begin{array}{l}\text { Clusters: Unmet. } 5,2,3,2 \\
\text { (c) Single: Metd 28 } \\
\text { Meting 2 } \\
\text { Unmet. 2 }\end{array}$ & Healthy \\
\hline $\begin{array}{l}\text { Exmouth high water, } \\
60-86 \text { mesh }\end{array}$ & $\begin{array}{l}\text { (a) Unmet,, large } \\
\text { number }\end{array}$ & (b) 1 or 2 & $\begin{array}{l}\text { Clusters: None } \\
\text { (c) Single: : Metd I2 } \\
\text { Meting 7 } \\
\text { Unmet. II } \\
\text { Unmers } \\
\text { Clusters : Meting 3 } \\
\text { Unmet. 8, 3,2 }\end{array}$ & Healthy \\
\hline $\begin{array}{l}\text { Exmouth high water, } \\
86-100 \text { mesh }\end{array}$ & $\begin{array}{l}\text { (a) Unmet., large } \\
\text { number }\end{array}$ & (b) None & 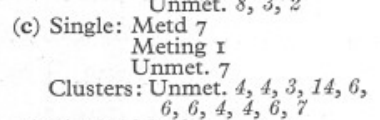 & Healthy \\
\hline $\begin{array}{l}\text { Exmouth high water, } \\
\text { I00-200 mesh }\end{array}$ & $\begin{array}{l}\text { (a) Unmet., large } \\
\text { number }\end{array}$ & (b) None & $\begin{array}{l}\text { (c) Single: Metd } 2 \\
\text { Meting I } \\
\text { Unmet. } 9 \\
\text { Clusters: Unmet. } 9,2,5,10,6, \\
5,6,7,2,12,3,10, \\
8,5,3,7,5\end{array}$ & Healthy \\
\hline $\begin{array}{l}\text { Exmouth high water, } \\
\text { recombined as Bull- } \\
\text { hill Bank, dish No. I }\end{array}$ & (a) Unmet. $175-200$ & (b) None & $\begin{aligned} & \text { (c) Single: } \text { Metd I6 } \\
& \text { Meting } 4 \\
& \text { Unmet. } 7 \\
& \text { Clusters: Unmet. } 5,5,7,5\end{aligned}$ & Very healthy \\
\hline $\begin{array}{l}\text { Exmouth high water, } \\
\text { recombined as Bull- } \\
\text { hill Bank, dish No. } 2\end{array}$ & (a) Unmet. c. I5O & (b) None & $\begin{array}{c}\text { (c) Single: Metd 30 } \\
\text { Meting 5 } \\
\text { Unmet. I, } d 2 \\
\text { Clusters: Meting } 5 \\
\text { Unmet. } 6\end{array}$ & Very healthy \\
\hline $\begin{array}{l}\text { Exmouth high water, } \\
\text { recombined as Bull- } \\
\text { hill Bank, dish No. } 3\end{array}$ & $\begin{array}{l}\text { (a) Unmet., large } \\
\text { number }\end{array}$ & (b) None & $\begin{aligned} & \text { (c) Single: } \text { Metd 22 } \\
& \text { Meting I } \\
& \text { Unmet. ० } \\
& \text { Clusters: Metd 2 } \\
& \text { Unmet. } 5,6\end{aligned}$ & Healthy \\
\hline $\begin{array}{l}\text { Exmouth high water, } \\
\text { recombined }+a \\
\text { little Bullhill sand }\end{array}$ & - & - & - & 一 \\
\hline
\end{tabular}




\section{TABLE VIII. Experiment 8 (cont.)}

I6. vii. 47

One on bottom meting. Others all unmet. with strong prototrochs and apical tufts. Healthy Bristles of third setiger very short

(a) Unmet. $70-80$

(b) None

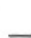

(a) Unmet., large number

(a) Unmet., fairly large number

(a) Unmet., many

(a) Unmet., a few

(a) Unmet., a few

(b) None

(c) Single: Metd o

Unmeting o

Clusters: Unmet. 3, 5, 7, 10,6
Metd moderately healthy;

Meting 2

Unmet. 5, $d$ II

Clusters: Meting 4

Unmet. 9, 5, 2, 2, 4

(c) Single: Metd 29

Meting I 4

Clusters: Unmet. 4, 3

(c) Single: Metd I5

Meting 5

Clusters: Unmet. 6, 3, 2

(c) Single: Metd 6

Meting 4

Clusters: Unmet. 6,4

c) Single: Metd o

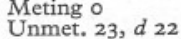

Unmet. 23,222
Clusters: Unmet. $2,2,2,3,5,10,2,4,4$ Unmet. $d 3,2,2,2,2,2$

Fairly healthy

Fairly healthy

Poor health

Some healthy, but others unhealthy (a) Unmet. c. 50

(a) Unmet., many (b) I or 2
(c) Single: Metd 34
Meting

Clusters: Meting

(b) None

(c) Single: Metd 38

Meting 4

Unmet. I
Clusters: Unmet. 2

Healthy

Healthy

Healthy

c) on bottom or in portion of sand. The italicized figures under 'clusters' (a) on surface film; (b) swimming; (c) on bottom or in portion of sand. The
give the number of larvae per cluster, each figure representing a single cluster. 


\section{Experiment 9}

This was a small experiment to test whether freshly collected and unboiled Bullhill sand was more active than sand which had been left a long time and had been boiled. The fresh sand had living Ophelia worms in it until used; it was washed only in warm and cold fresh water and filtered sea water. The result (Table IX) reveals no significant difference. In the same experiment two grades of 'Gritty' sand were also tested, and it is to be noted that both had almost no effect in promoting metamorphosis, although one of the grades had a grain size equivalent to that most commonly found in the Bullhill Bank. In all these dishes, and in the clean dish in which no metamorphosis took place, the larvae were strong and healthy, but in a dish containing B.D.H. acid-purified sand recombined in the proportions by weight of the Bullhill Bank sand almost all the larvae were dead or dying and none was in good condition. In all previous experiments with this sand the larvae had been adversely affected in spite of the sand being well boiled and well washed before use. The reason for this apparently lethal action (it seems too improbable to assume chance bacterial infection is the cause here) is unknown.

\section{EXPERIMENTS ON CHOICE OF BOTTOM}

In none of the experiments so far described were the larvae given a choice of sands in which to settle. Each dish contained only one kind of soil, or none at all. In order, therefore, to test the selective powers of the larvae another type of experiment was needed, one in which the larvae were afforded the opportunity to settle in one or more different kinds of sand in the same dish.

\section{Experiment Io}

This was designed to test the ability of larvae to find a small area of suitable sand placed in the centre of a large dish. A Petri dish of $9 \mathrm{~cm}$. internal diameter had a small patch of Bullhill sand less than $2 \mathrm{~cm}$. in diameter in the middle of the dish. A large number of actively swimming larvae were put into the dish, which was covered and left undisturbed in a cool place. This experiment began on I2 June I946 with larvae from a fertilization of 5 June. The larvae were beginning to use their anal papillae for attachment. On I9 June the dish was carefully examined and the result is shown in Table X. There were twenty unmetamorphosed larvae stuck to the surface film, while on the bottom, away from the sand, 226 larvae were counted. Of these four were metamorphosed, but were near the sand and had probably crawled out of it. One other was metamorphosing. All the remainder were unmetamorphosed, some attached singly to the glass, but over half of them stuck to bits of cotton and other debris. One long cotton fragment had about seventy larvae attached. In the sand were seventy-nine metamorphosed healthy-looking worms with others metamorphosing and unmetamorphosed, making in all a total of I40. 


\section{TABLE IX. EXPERIMENT 9}

(Begun 17. vii. 47 with larvae from a fertilization of 7. vii. 47.)

\begin{tabular}{|c|c|c|c|c|c|c|c|}
\hline Clean dish & (a) & Unmet. many & (b) & A few & (c) & Unmet. many & Healthy \\
\hline \multirow[t]{2}{*}{$\begin{array}{l}\text { I2 months old Bullhill Bank } \\
\text { natural }\end{array}$} & (a) & Unmet. c. roo & (b) & None & (c) & $\begin{aligned} \text { Single: } & \text { Metd II } \\
& \text { Meting } 6 \\
& \text { Unmet. I4 }\end{aligned}$ & Healthy \\
\hline & & & & & & Clusters: None & \\
\hline \multirow[t]{2}{*}{$\begin{array}{l}\text { Freshly collected Bullhill } \\
\text { Bank natural }\end{array}$} & (a) & Unmet. c. I00 & (b) & None & (c) & $\begin{aligned} \text { Single: } & \text { Metd II } \\
& \text { Meting } 7 \\
& \text { Unmet. } 8\end{aligned}$ & Healthy \\
\hline & & & & & & Clusters: None & \\
\hline \multirow[t]{2}{*}{ 'Gritty' sand, 40-60 mesh } & (a) & Unmet. c. 8 & (b) & Small number & (c) & $\begin{aligned} \text { Single: } & \text { Metd o } \\
& \text { Meting } 3 \\
& \text { Unmet. I3 }\end{aligned}$ & Healthy \\
\hline & & & & & & Clusters: None & \\
\hline \multirow[t]{2}{*}{ 'Gritty' sand, 100-200 mesh } & (a) & Unmet. c. 60 & (b) & A few & (c) & $\begin{aligned} \text { Single: } & \text { Metd o } \\
& \text { Meting } 2 \\
& \text { Unmet. 15 }\end{aligned}$ & Healthy \\
\hline & & & & & & Clusters: Unmet. $2,6,3,10,12$ & \\
\hline \multirow[t]{2}{*}{$\begin{array}{l}\text { B.D.H. sand, acid-purified, } \\
\text { recombined as Bullhill } \\
\text { Bank }\end{array}$} & (a) & $\begin{array}{l}\text { Unmet. c. } 20 \text {, several dead } \\
\text { or dying }\end{array}$ & (b) & None & (c) & $\begin{aligned} \text { Single: } & \text { Metd o } \\
& \text { Meting I } \\
& \text { Unmet. but dead } 5\end{aligned}$ & $\begin{array}{l}\text { Nearly all dead } \\
\text { or dying }\end{array}$ \\
\hline & & & & & & Clusters: None & \\
\hline
\end{tabular}

(a) on surface film; (b) swimming freely; (c) in portion of sand. The italicized figures under 'clusters' give the number of larvae per cluster, each figure representing a single cluster. 
To these should probably be added the four metamorphosed worms found on the glass close by. A simple calculation shows that in the sand larvae had congregated to the extent of about forty-eight to the sq.cm., whereas on the glass bottom the density was only about $2 \cdot 4$ to the sq.cm. This latter figure, of course, assumes even distribution and ignores the actual great local concentration on cotton fragments, which is probably something that would not occur in the sea.

\section{TABLe X. Experiment io}

(Result on I9. vi. 46.)

$\begin{array}{lccc} & \text { On surface film } & \text { On glass } & \text { In sand } \\ \text { Metd } & \circ & 4 & 79 \\ \text { Meting } & \circ & \text { I } & 25 \\ \text { Unmet. } & 20 & 83 ; 70,4,9,6,8,8,5,8,7,8,5 & 36 \\ \text { Total } & 20 & 226 & \text { I40 }\end{array}$

When clusters were present, the figures are given separately in italic, each figure representing a single cluster.

From the result it appears that larvae, once they have come into contact with the sand, tend to stay there and metamorphose. As all the larvae in the dish were not in the sand, most of them, indeed, being away from it, it seems unlikely that the sand exerts any sort of chemical attraction for them over a distance. They probably find it by chance contact while swimming about. It is probable, too, that more larvae would have reached the sand had they not first become stuck to the glass or surface film, or trapped by cotton fragments in such a manner that they were unable to detach themselves. In moving water, such as would occur in nature, it is probable that detachment from the bottom would have been facilitated. In nature, too, cotton and other dust particles can hardly be such a menace as they are in laboratory dishes.

\section{Experiment II}

This was similar to Exp. Io, but two patches of sand were used, one of Bullhill Bank sand and the other sand from Penrhyn Bay. Each little heap of sand was about $1.5 \mathrm{~cm}$. in diameter, and their centres were $4.5 \mathrm{~cm}$. apart in a Petri dish of $9.0 \mathrm{~cm}$. internal diameter. The dish was kept in a cupboard in the dark for the first $36 \mathrm{hr}$. and then on a cool shelf near the sea-water circulation. The experiment began on II July 1946 with swimming larvae from a fertilization made on I July 1946. The dish was examined and the larvae counted on I6 July 1946. It was found that Skeletonema chains and a small naviculoid diatom covered the bottom in large numbers and the larvae both on the glass and in the sands were badly fouled with them, the diatoms sticking to their bristles. A number of larvae were dead, while the living ones were in poor condition. In setting up these early experiments the water was not filtered as it was in later experiments after the necessity for so doing had become apparent. 


\section{TABLE XI. EXPERIMENT II}

\begin{tabular}{|c|c|c|c|}
\hline \multicolumn{4}{|c|}{ (Result on I6. vii. 46.) } \\
\hline & On glass & In Bullhill sand & In Penrhyn Bay sand \\
\hline $\begin{array}{l}\text { Metd } \\
\text { Meting } \\
\text { Unmet. }\end{array}$ & $\begin{array}{rl}4 & \\
9 & \\
86 & d 24\end{array}$ & 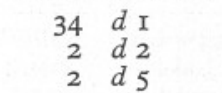 & $\begin{array}{ll}8 & \\
\mathrm{I} & d \mathrm{I} \\
\circ & d\end{array}$ \\
\hline Total & I23 & 46 & 13 \\
\hline
\end{tabular}

In spite of the poor condition of the larvae, doubtless to a large extent brought about by this excessive concentration of diatoms, the result of the experiment (see Table XI) is interesting. There was a greater concentration of larvae in the Bullhill sand than in the Penrhyn Bay sand and a greater concentration in both sands than on the glass. The figures per sq.cm. give for the Bullhill sand 20 larvae, Penrhyn Bay sand about 5.6 and for the glass I. 3 larvae. On the glass there were a few small clusters of larvae, but most of them were scattered singly about the dish.

The original notes on this experiment make no mention of larvae caught on the surface film. It can be assumed that either none was present or the numbers were small, and not being specially noteworthy were accidentally omitted when recording the result.

\section{Experiment I2}

This was similar to the last, but was made the following summer. Some slight changes were introduced in the arrangement. Smaller Petri dishes, only $7 \mathrm{~cm}$. internal diameter, were used, and the sands were confined within shallow glass rings of the kind used in making microscopic mounts of large objects. These rings were of $\mathrm{I} \mathrm{cm}$. internal diameter; they were placed loosely on the bottoms of the Petri dishes and were not cemented into place. As usual all glassware was acid cleaned and well washed before use.

Three dishes were used; in each one or more sands were tested against Bullhill Bank sand. The experiment began on I4 June I 947 with larvae from a fertilization of 9 June. It was a healthy culture with the larvae still mainly swimming and with few attaching. The larvae actively moved away from a source of light. The dishes were kept on black paper and were covered with glass sheets and tissue paper in a cool place.

The experiment was ended on 30 June and I July when the dishes were examined and the larvae in the sands counted. In counting the larvae in the sands great care was taken to ensure that every one was found and it is thought improbable that any escaped observation. The results are shown in Table XII. Larvae on the surface film and bottom were noted, but not counted. In all dishes there was a large number of larvae on the surface film as well as on the bottom; clusters of larvae were often attached to cotton fragments. 


\section{TABLE XII. EXPERIMENT I2}

(Result on 30. vi. 47 and I. vii. 47.)

\begin{tabular}{|c|c|c|c|c|c|c|c|}
\hline & \multicolumn{2}{|c|}{ Dish A } & \multicolumn{2}{|c|}{ Dish B } & \multicolumn{3}{|c|}{ Dish C } \\
\hline & $\begin{array}{l}\text { Bullhill } \\
\text { Bank } \\
\text { sand }\end{array}$ & $\begin{array}{l}\text { Salthouse } \\
\text { Lake } \\
\text { sand }\end{array}$ & $\begin{array}{l}\text { Bullhill } \\
\text { Bank } \\
\text { sand }\end{array}$ & $\begin{array}{l}\text { Polzeath } \\
\text { sand }\end{array}$ & $\begin{array}{l}\text { Bullhill } \\
\text { Bank } \\
\text { sand }\end{array}$ & $\begin{array}{l}\text { Kames } \\
\text { Bay } \\
\text { sand }\end{array}$ & $\begin{array}{l}\text { 'Gritty' } \\
\text { sand }\end{array}$ \\
\hline Metd & 23 & 8 & 43 & $2 \mathrm{I}$ & 80 & 30 & 30 \\
\hline Meting & 3 & 6 & II & II & 22 & I3 & $\mathrm{I} 2$ \\
\hline $\begin{array}{l}\text { Possibly } \\
\text { meting }\end{array}$ & I & 9 & I & 9 & 6 & 8 & Io \\
\hline Unmet. & $5 ; 6$ & I3 & 2 & $15 ; 3,7$ & I4 & $3 ; 2$ & $22 ; 6,3$ \\
\hline $\begin{array}{l}\text { Dead } \\
\text { unmet: }\end{array}$ & I & I & I & 2 & I & I & - \\
\hline Total & 39 & 37 & 58 & 68 & I 23 & 57 & 83 \\
\hline
\end{tabular}

When clusters were present, the figures are given separately in italic, each figure representing a single cluster.

From Table XII it will be seen at once that as in so many other experiments the Bullhill Bank sand yielded more fully metamorphosed young worms than did sand of other kinds. Moreover, the young worms in the Bullhill Bank sand were always the healthiest of the lot, those in the Salthouse Lake sand and the Polzeath sand in particular being in rather poor condition. The total number of worms and larvae in the Bullhill Bank sand was generally larger than in the others, though unmetamorphosed larvae in some abundance raised the total figure for the Salthouse Lake, Polzeath and 'Gritty' sands. In removing the sands for examination care had been taken to avoid falsification of the result by accidental mixing with unmetamorphosed larvae from the surface film, but this may not have been avoided altogether. Clusters are to be specially suspect as having fallen into the sands from the surface film when the dishes were disturbed.

It was often difficult in this experiment to be sure of the correct classification of unmetamorphosed and metamorphosing larvae. Some of the former had lost their cilia, but no other changes were noticeable. The health of these stages in the sands was not as good as that of most of the fully metamorphosed young worms, or as good as that of the larvae on the surface film or on the glass bottom of each dish.

Although no actual calculation was made, it was obvious to the eye that the concentration of the larvae per unit area of clear glass bottom was much less than in any of the sands.

The larvae on the surface film or on the bottom were almost all unmetamorphosed, though a very few on the bottom were metamorphosed or metamorphosing, and it is just possible they may have crawled out of the sand. It was noted in all three dishes that the larvae on the surface film nearly all had strong prototrochs and apical tufts, whereas those on the glass bottom were not quite so healthy and there was some tendency to loss of cilia, some from 
the prototroch but especially the apical tufts, as though contact with the hard surface of the bottom served as a slight stimulus towards metamorphosis. This has also been noticed in other experiments.

While not satisfactory in every respect, this experiment does show once again the relatively greater readiness of the larvae to enter Bullhill Bank sand than any other kind, and that once there they are likely to metamorphose without delay.

\section{Experiment I3}

Three small dishes of $3 \mathrm{~cm}$. internal diameter were each divided into two sections by placing across the bottom a narrow strip of glass cut from a microscope slide. On one side of the strip the bottom was covered with Bullhill Bank sand, on the other with a natural sand of another sort. Larvae could readily pass from one sand to the other by swimming over the strip. Sands were sterilized by boiling and then were well washed in fresh and filtered sea water in the usual way; the dishes were filled with filtered sea water. Larvae 5 days old were put into the dishes on 8 July 1947. Each dish was surrounded by a collar of black paper and covered by a glass plate, but as in Exp. 8, which ran concurrently, this method failed to prevent large numbers of larvae attaching themselves to the surface film.

The dishes were not examined until I8 July when it was seen that in each instance 100-200 larvae were on the surface film, almost all of them unmetamorphosed, though a few had rather long bristles on the third setiger whilst still retaining a well-ciliated prototroch. This was unusual. These surface-film larvae were carefully removed and the surfaces of the sands then searched with a low-power binocular. Several clusters of larvae stuck together were seen, as well as single unmetamorphosed larvae sitting upright on their anal papillae attached to sand grains, their prototrochs beating actively, causing heads and bodies to wave about as though endeavouring to get free. Sometimes metamorphosed worms could also be seen. The clusters were removed, as it was considered that they were to a large extent an unnatural formation due to the great concentration of larvae in a relatively small volume of water. The larvae could hardly avoid contact with particles of debris and with one another, and they readily adhered by the mucus they secreted. Thus all clusters seen on the surface were removed, but the subsequent search of the sands showed that many had become buried and the larvae forming them often metamorphosed, though it is possible that some of the clusters were formed after metamorphosis owing to the great concentration in what was relatively a very small amount of sand. Against this is the significant fact that, whereas in dish $\mathrm{C}$ the majority of the larvae in the clusters found in the sand were unmetamorphosed (see Table XIII), those in dishes D and E, examined 4 and 5 days later respectively, were mainly all metamorphosed, suggesting that metamorphosis of larvae clustered together does take place when the clusters are buried in sand. 


\section{TABLE XIII. EXPERIMENT I3}

Dish C (examined 18. vii. 47)

\begin{tabular}{|c|c|c|c|c|}
\hline & & 11 Bank sand & Sal & se Lake sand \\
\hline & Singles & Clusters & Singles & Clusters \\
\hline Metd & 37 & 5 & I2 & None \\
\hline $\begin{array}{l}\text { Meting } \\
\text { Possibly meting }\end{array}$ & 20 & $2,3,3,2$ & I7 & 2,2 \\
\hline $\begin{array}{l}\text { Possibly meting } \\
\text { Unmet. }\end{array}$ & I5 & None & II & \\
\hline Unmet. & 23 & $\begin{array}{l}2,5,12,6,8,5, \\
8,3,7,7,8,6, \\
4,3,3\end{array}$ & $3 \mathrm{I}$ & $\begin{array}{c}3,7,2,6,2,6, \\
4,5,4,6,3,6, \\
4,6,6,3,4\end{array}$ \\
\hline Dead & 2 & - & I & None \\
\hline Totals & 97 & I96 99 & 72 & I55 83 \\
\hline
\end{tabular}

Dish D (examined 22. vii. 47)

\begin{tabular}{|c|c|c|c|c|}
\hline \multirow[b]{3}{*}{ Metd } & \multicolumn{2}{|c|}{ Bullhill Bank sand } & \multicolumn{2}{|c|}{ Polzeath sand } \\
\hline & Singles & Clusters & Singles & Clusters \\
\hline & 78 & $\begin{array}{l}2,3,4,5,6,6, \\
5,4,2,5,4,4, \\
5,2\end{array}$ & 36 & $3,3,4,3,4$ \\
\hline $\begin{array}{l}\text { Meting } \\
\text { Possibly meting } \\
\text { Unmet. } \\
\text { Dead }\end{array}$ & $\begin{array}{l}\text { 3 } \\
\text { None } \\
\text { None } \\
\text { None }\end{array}$ & $\begin{array}{l}2 \\
\text { None } \\
\text { None } \\
\text { None }\end{array}$ & $\begin{array}{c}3 \\
\text { None } \\
3 \\
\text { None }\end{array}$ & $\begin{array}{l}3,4,2,2,8 \\
\text { None } \\
12,8,4 \\
\text { None }\end{array}$ \\
\hline Totals & $8 \mathrm{I}$ & $\mathrm{I} 40 \quad 59$ & 42 & 10260 \\
\hline
\end{tabular}

Dish E (examined 23. vii. 47)

Bullhill Bank sand

\begin{tabular}{|c|c|c|c|c|}
\hline & Singles & Clusters & Singles & Clusters \\
\hline Metd & I30 & $\begin{array}{l}5,3,5,2,4,2, \\
4,3,2\end{array}$ & II 4 & $\begin{array}{r}3,9,3,7,5,6, \\
4,5,9,3,3,5, \\
6,5,4,4,5,3,\end{array}$ \\
\hline $\begin{array}{l}\text { Meting } \\
\text { Possibly meting } \\
\text { Unmet. } \\
\text { Dead }\end{array}$ & $\begin{array}{l}\text { 3 } \\
\text { None } \\
\text { None } \\
\text { None }\end{array}$ & $\begin{array}{l}\text { None } \\
\text { None } \\
\text { None }\end{array}$ & $\begin{array}{c}\text { ro } \\
\text { None } \\
3 \\
\text { None }\end{array}$ & $\begin{array}{l}6,4 \\
\text { None } \\
4 \\
\text { None }\end{array}$ \\
\hline Totals & I33 & $166^{33}$ & I27 & $239^{112}$ \\
\hline
\end{tabular}

The italicized figures under 'clusters' give the number of larvae per cluster, each figure representing a single cluster.

If in interpreting the results (Table XIII) only single larvae are considered, the usual relative distribution of the larvae among the sands is seen. The Bullhill Bank sand always collects most and induces earlier metamorphosis in the majority of those collected. This is also true in dishes C and D of the clusters as well, but in dish $\mathrm{E}$ the usual conditions as regards numbers are reversed. There is no doubt that the formation of clusters in a high concentration of larvae is an unfortunate complication in experiments of this kind, and so is the absence of natural currents to assist the detachment of larvae 
endeavouring to pull themselves free from surface sand grains to which they have become too strongly fastened by their anal papillae.

The health of the larvae in dish $\mathrm{C}$ was not very good; there were some small ciliates in this dish and some of the larvae were being attacked. In dish D the metamorphosed worms in the Polzeath sand were definitely unhealthy, stumpy and not well formed. Those in the Bullhill sand of the same dish were on the whole healthier and livelier and better formed. The health of dish $\mathrm{E}$ was good and the metamorphosed worms in both kinds of sand were in good condition, but again those in the Bullhill sand seemed superior in this respect. They had on the whole larger bodies, longer bristles and a generally better appearance of well-being.

\section{General CONCLUSIONS}

Additional experiments are planned for the future, and therefore it is not thought fitting at this stage to enter into a complete discussion of the results so far obtained, nor to consider exhaustively the literature bearing on the subject. Some major points have, however, emerged, and it is right that these should be summarized. Some comparison with Jägersten's remarkable results must also be made.

Jägersten (I940) worked with larvae of Protodrilus rubropharyngeus Jägersten which he obtained by tow-netting. In a series of extremely interesting experiments he found that in the shell gravel in which this particular species of Protodrilus lives, and apparently also in other gravel of similar character, there is a metamorphosis-producing substance, inorganic in nature and extremely resistant to boiling in water, incineration, treatment with alcohol, formalin, acids, etc. It can be destroyed by prolonged soaking in fresh water and by boiling for $2 \mathrm{hr}$. in nitric acid, but not by several hours' boiling in sulphuric and hydrochloric acids or sodium hydroxide. Jägersten states that quite a small fragment from shell gravel containing the substance will cause Protodrilus larvae to metamorphose when it is placed with them in an otherwise clean dish of sea water. Moreover, small stones of granite, etc., can be activated by contact, for one or two days, with active gravel particles, and these small stones will bring about metamorphosis if dropped into a dish containing swimming larvae. Even sea water which has been standing for some weeks over active shell gravel will by itself induce metamorphosis reactions. The metamorphosis-producing substance can be filtered off from such water, the filter paper used becoming active, the filtered water inactive. Thus Protodrilus larvae react, not to the physical nature of the bottom soil, but to some obscure chemical substance which dissolves only slowly in water and is remarkably stable when treated with a great variety of reagents.

In a previous paper (Wilson, I937) I suggested that larvae such as those of Scolecolepis, in which the adult occupies a fairly well-defined zone on the shore, select not merely mud as such but that they are perhaps most 
strongly attracted to mud inhabited by the adults. I had in mind some sort of chemotaxis to the ancestral home. It has always seemed possible that the larvae of a gregarious species such as Sabellaria alveolata (in which, so far as is known, asexual reproduction does not occur), which forms huge honeycomb masses of sandy tubes on suitable shores, may be strongly attracted by the presence of adults or young worms already settled and be induced to settle alongside them. If this be so, it seems likely that the larvae perceive the presence of the adult worms by some sense other than the tactile one. I was thus fully prepared to find that Ophelia larvae would show some chemical perception of the sand in which the adults had been living, and some of the experiments were designed to test for this. So far all the results directed to this end have been negative and all positive results have indicated that actual physical contact with the sand, perceived most probably by the tactile sense, is the stimulus to metamorphosis. This stimulus is strongest when the grade of the sand and the shapes of the particles composing it are identical with that of the sand from the Bullhill Bank in which the adults live. The more the character of a sand departs from that of the Bullhill Bank the less readily will larvae metamorphose in it. Mineral composition is probably not so important a factor as shape and size of the sand grains-well-rounded smooth grains, the majority of which pass 40 meshes to the inch but are retained by 86 meshes to the inch, are the main requirement, and the sand must be loose and clean. It is probably not so much the size and shape of the grains which is the stimulus to metamorphosis as the sizes and shapes of the interstices among the grains. It should be remembered that the larvae at metamorphosis are in length onethird to one-half the diameter of the commonest sizes of sand grains present in the Bullhill Bank sand (see Plate XV, figs. I-3). It may well be, therefore, that smooth rounded grains, each in diameter two to three times the length of the larvae, have among them interstices of sizes and shapes giving degrees of contact with the body of the larva crawling amongst them that induce it to remain there and metamorphose. In other words, if it feels right, it $i$ right, and the larva seeks no further.

The experiments described in this paper give no indication at all that Bullhill Bank sand, or any of the other sands such as that from Penrhyn Bay which is a moderately efficient stimulus to metamorphosis, contain any slowly dissolving substance that brings about metamorphosis as in the manner of the shell gravel which is active for Jägersten's Protodrilus. The indications are, indeed, all against it. The fact that by mixing Carborundum grit with the Bullhill sand metamorphosis is long delayed or prevented altogether is more easily explained on the physical theory than the chemical. So, too, is the effect of cementing the sand in a single layer on the bottom of the dish so that the grains are immovable, though only bedded in the cement on their undersides, leaving most of their surfaces free to release any soluble substances they might contain. It seems that the grains must be movable as well as of the 
right shapes and sizes; a single layer of grains anyhow will hardly produce interstices comparable to those in a pile of sand. Larvae on surface films just above Bullhill sand hardly ever metamorphose, though they may be there for several days, and the same is true of larvae on the glass bottoms of dishes containing restricted piles of the sand. Larvae are not chemically attracted to these piles but seem to find them by chance contact. Moreover, the finest grades of Bullhill sand, though composed of the same minerals and presumably containing the same, if any, soluble matter as the coarser grains are almost as inactive in a metamorphosis producing sense as are Carborundum grit and sands of sharp angular particles. On the other hand, a proportion, though admittedly a very small proportion, of larvae can be induced to metamorphose by supplying fragments of broken cover-glass or glass wool (Exp. 4), substances unlikely to contain a soluble metamorphosis-producing substance but which might now and again produce interstices of appropriate sizes and shapes which, if found by larvae, would be mistaken for the proper environment. The same remark applies, of course, to the Eddystone shell gravel, gritty sands of angular particles and other unsuitable soils where some of the larvae metamorphosed.

This difference between the reactions of Ophelia larvae and those of Protodrilus as reported by Jägersten is, of course, in no sense a contradiction of Jägersten's work or of the conclusions he has drawn from it. Neither does my work rule out entirely the possibility of some chemical perception of the grains at close range being employed by the larvae, although it makes such a possibility seem improbable.

Ophelia larvae kept indefinitely under clean conditions or with the wrong kind of substratum either die without metamorphosing or eventually make some attempt to metamorphose. This often consists only in the loss of cilia, but sometimes metamorphosis is successful and more or less normal young worms are produced. Much seems to depend on the health of the larvae at the time, and really healthy larvae seem to last longer without showing signs of metamorphosis than do less healthy ones. In clean dishes the larvae on the bottom as a rule show incipient signs of metamorphosis sooner than do those on the surface film; it is as though contact with something solid does in itself constitute some degree of stimulus quite apart from consideration of shape and size.

The possession by pelagic larvae of the ability to choose the right substratum during a period of time that may amount to several weeks in some species, as in Ophelia, is undoubtedly of especially great advantage to those species that are confined when adult to a particular kind of bottom soil, or any other form of restricted type of habitat. It is not intended here to enter fully into the implications on ecological distribution and similar fields of inquiry which this discovery opens up. Points concerning it were made in an earlier paper (Wilson, I937), and Thorson (I946) has recently discussed the subject 
at some length and has described some experiments with bottle collectors that 'seem to support the conjecture that marine bottom invertebrates are able to actively choose their substratum' (p. 465).

In the Exe estuary there are a variety of bottoms, some differing widely from the conditions on the top of the Bullhill Bank where Ophelia reaches its maximum abundance. The larvae, by their ability to distinguish between the various types and by their selection only of those which are appropriate for adult life, are led to concentrate in the latter and so maintain the normal distribution of the species in the estuary. The pelagic stages will be carried to and fro in and out of the estuary with the tidal currents, and whilst some may be lost out to sea it seems probable that the main swarm does not get dispersed to distant places but remains about the estuary mouth. This must be so, otherwise the species would not be able to maintain itself in that locality, for as far as is known it is not present on outside shores or grounds in the immediate vicinity of the Exe, though full investigation has not yet been made.

Among the grounds over which Ophelia larvae will be carried will be the Salthouse Lake area already mentioned. The sand of this area is, as we have seen, generally of a finer grade, more compact and not quite as clean as is the looser sand of the Bullhill Bank. It supports a normal sand fauna with a relatively few Ophelia present in some areas. The samples of sand from these areas which have so far been analysed showed a preponderance of grains between the 60- and 100-mesh sizes, but there was a higher proportion of grains between the 40- and 60-mesh sizes than in the Salthouse Lake sample used in the experiments and whose composition is given on p. 735 . This latter sand is, as was seen in Exps. 7, I2 and I3, not as effective in bringing about metamorphosis as is the Bullhill Bank sand, and it may be presumed that the rather similar sand from the Salthouse Lake area where a few Ophelia may be found (about I2 per m. ${ }^{2}$ as against up to 268 per m..$^{2}$ on the Bullhill Bank, according to $\mathrm{Mr}$ N. A. Holme's figures-private communication) would likewise be relatively unattractive to the larvae. If this be so, we have a reasonable explanation of the observed distribution of Ophelia in the Exe estuary, a heavy concentration in the metamorphosis-stimulating sand of the Bullhill Bank and the Polesands, with a much lower concentration in the less stimulating Salthouse Lake area. As the larvae in the later pelagic stages drift over the banks the majority of these coming into contact with the Bullhill sand will enter it and stay there, but of those washed over the Salthouse Lake only a small proportion will settle, the majority will leave the sand after testing it and, continuing pelagic life, may later on eventually reach the Bullhill Bank or the almost equally suitable Polesands nearer the open sea. This explanation is at least as reasonable as supposing that there is an even settlement over the whole area followed by greater destruction of the young worms in the unfavourable soils, and the results of these experiments support it. 


\section{SUMMARY}

Experiments with larvae of Ophelia bicornis Savigny have shown that they metamorphose most readily in sand from their natural habitat and with hesitancy or not at all in sands from other sources. Their natural sand consists largely of smooth rounded grains of quartz, very uniform in size; sands of smaller and more angular grains are unfavourable to settlement and metamorphosis. It appears that size and shape of the sand grains, or perhaps, more likely, the sizes and shapes of the interstices among the grains, perceived probably by the tactile sense, is the main stimulus to metamorphosis. Chemical substances dissolving out of the sands do not seem to be responsible for this.

There is a period of time, amounting under favourable conditions to several weeks, during which an Ophelia larva is able to settle and metamorphose as soon as it comes into contact with a substratum suitable for adult life.

The ability of the larvae to distinguish bottom deposits suitable for adult life from those which are unsuitable must be of great advantage to the species in maintaining normal distribution and in conserving larvae.

Larvae kept indefinitely in glass dishes without sand, or with a deposit of the wrong kind, eventually either die without metamorphosing or attempt to do so with greater or less success.

\section{REFERENCES}

Allen, E. J. \& Todd, R. A., I902. The fauna of the Exe Estuary. Fourn. Mar. Biol. Assoc., Vol. vi, pp. 295-335.

DAY, J. H. \& WILSON, D. P., I934. On the relation of the substratum to the metamorphosis of Scolecolepis fuliginosa (Claparède). Fourn. Mar. Biol. Assoc., Vol. XIX, pp. 655-62.

JÄGERSTEN, G., I940. Die Abhängigkeit der Metamorphose vom Substrat des Biotops bei Protodrilus. Arkiv f. Zool. (Stockholm), Bd. 32A, No. I7, pp. I-I2.

Thorson, G., I946. Reproduction and larval development of Danish marine bottom invertebrates. Medd. Komm. Danmarks Fisk. Havund., Ser. Plankton, Bd. 4, pp. I-523.

WILson, D. P., I932. On the Mitraria larva of Owenia fusiformis Delle Chiaje. Phil. Trans. Roy. Soc., Ser. B, Vol. 22I, pp. 23I-334.

- 1937. The influence of the substratum on the metamorphosis of Notomastus larvae. Fourn. Mar. Biol. Assoc., Vol. xxir, pp. 227-43.

- I948. The larval development of Ophelia bicornis Savigny. Fourn. Mar. Biol. Assoc., Vol. xxvII, pp. 540-53. 


\section{EXPLANATION OF PLATES}

\section{Plate XV}

Photomicrographs of living Ophelia larvae, $\times 50$.

Fig. I. Unmetamorphosed larva attached to a sand grain by the anal papillae. The larva is squat in shape and the region of the prototroch is dark and distinct.

Fig. 2. Larva in early metamorphosis crawling on the bottom of a glass dish. The larva is elongating and the dark prototrochal tissues are less distinct.

Fig. 3. Two metamorphosed larvae on a large sand grain; one is attached by the anal papillae, the other is crawling round the grain. The body is longer and the head narrower than before and no dark prototrochal tissue remains. The central portion of the gut is dark and distinct. In the original photograph the long bristles are visible, but are likely to be lost in the reproduction.

Fig. 4. Cluster of about one hundred unmetamorphosed larvae attached to a cotton fragment.

All larvae were from the same experiment and were 13 days old. The cluster was from a clean dish without sand, the others were from a dish containing Bullhill Bank sand. Photographed in July I948 with electronic flash apparatus using a Mullard LSD 3 flashtube. Duration of exposure about $\frac{1}{3000} \mathrm{sec}$.

\section{Plate XVI}

Photomicrographs of sands, $\times 2 \mathrm{I}$.

Fig. 1. Bullhill Bank sand.

Fig. 2. Bullhill Bank sand, 86-100 mesh.

Fig. 3. Salthouse Lake sand.

Fig. 4. Kames Bay sand.

\section{Plate XVII}

Photomicrographs of sands and 'Grits', × 2 I.

Fig. I. Penrhyn Bay sand.

Fig. 2. Polzeath sand.

Fig. 3. Fine 'Gritty' sand.

Fig. 4. Carborundum grit No. I2O. 

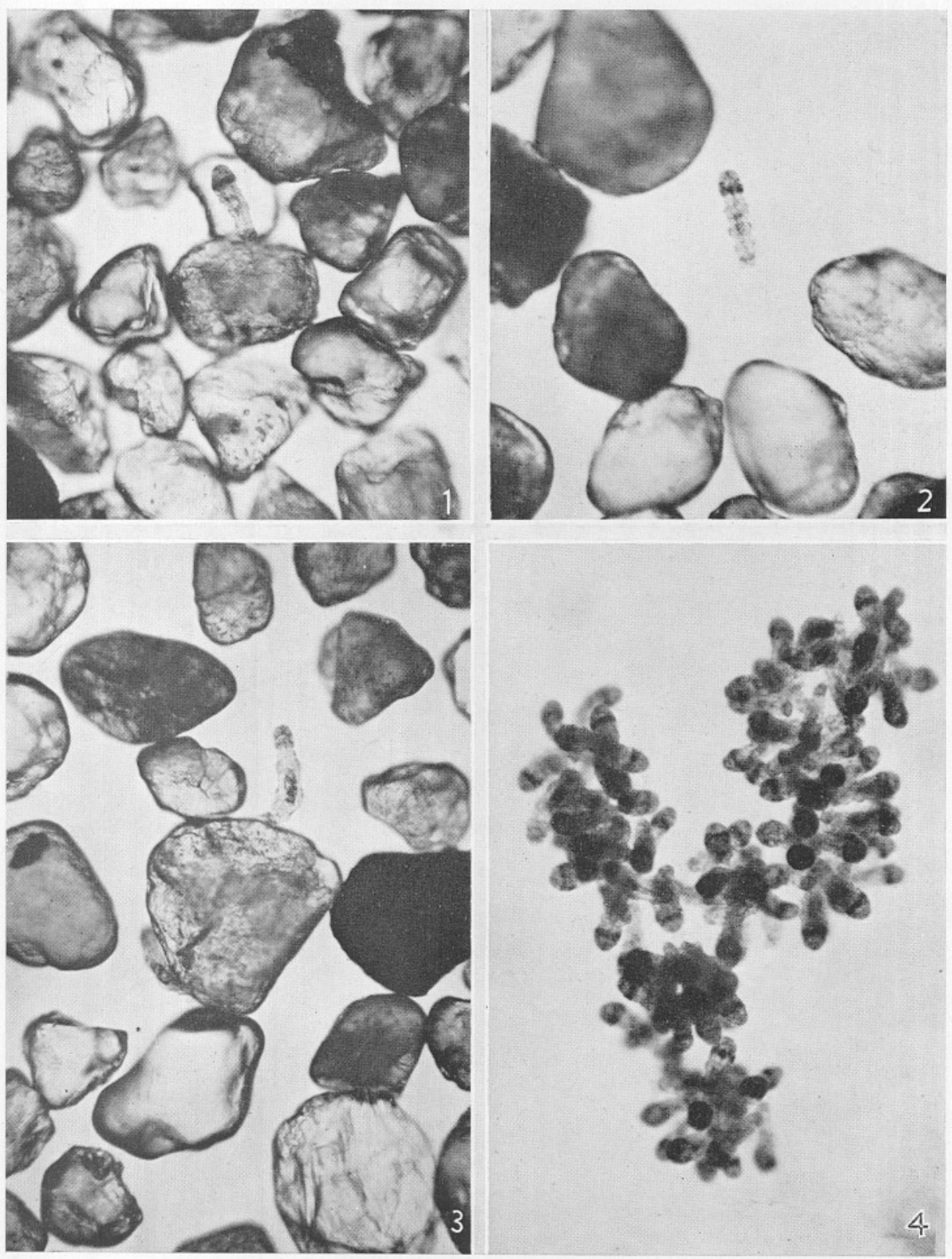

Figs. I-4. 

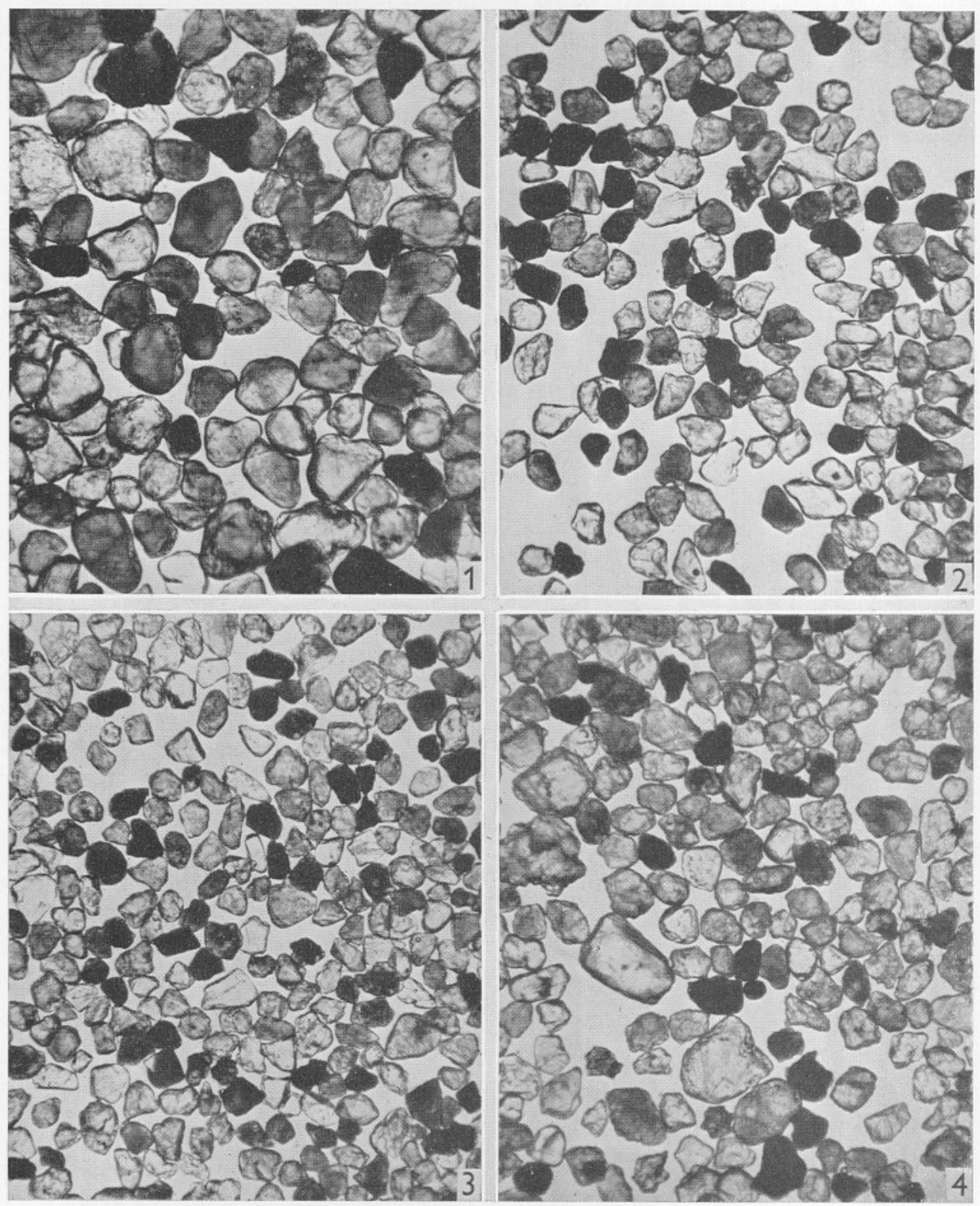

Figs. I-4. 

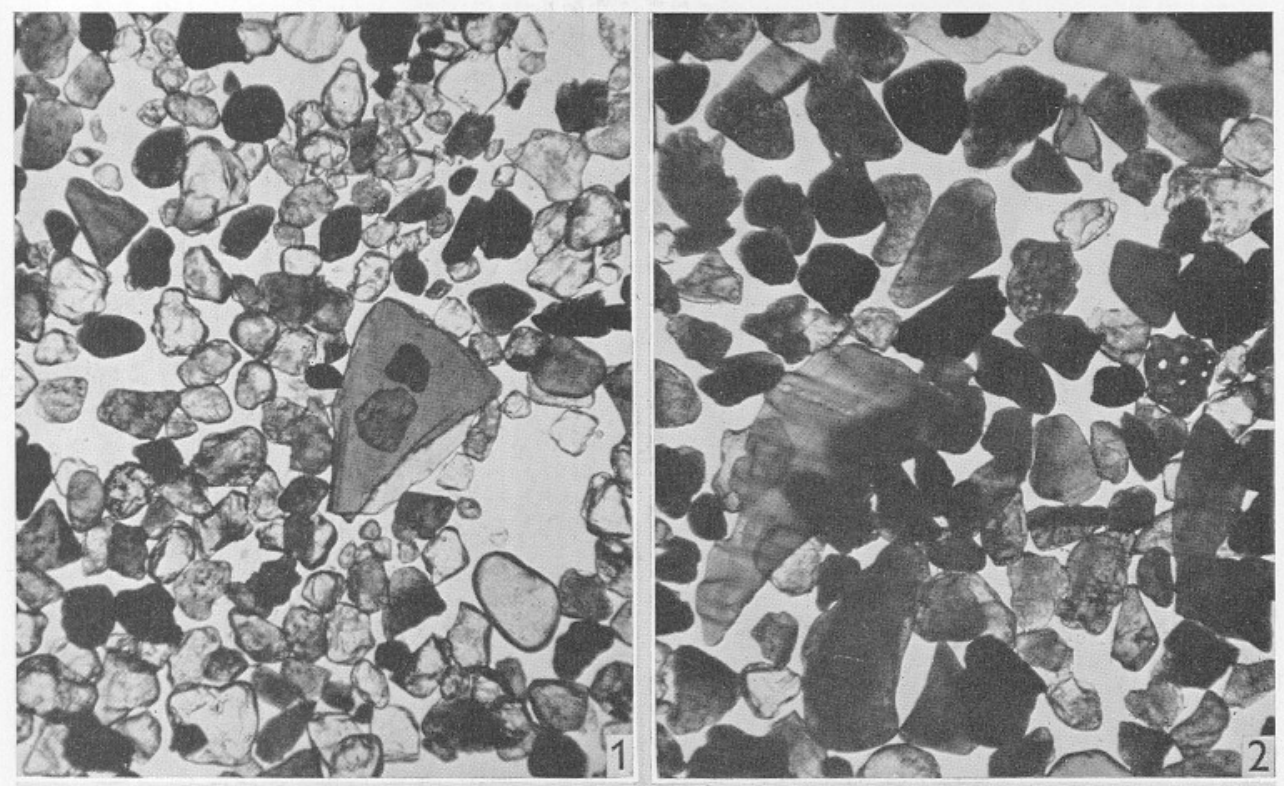

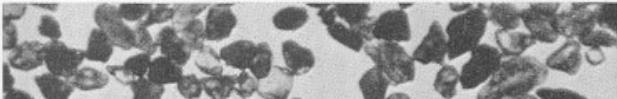

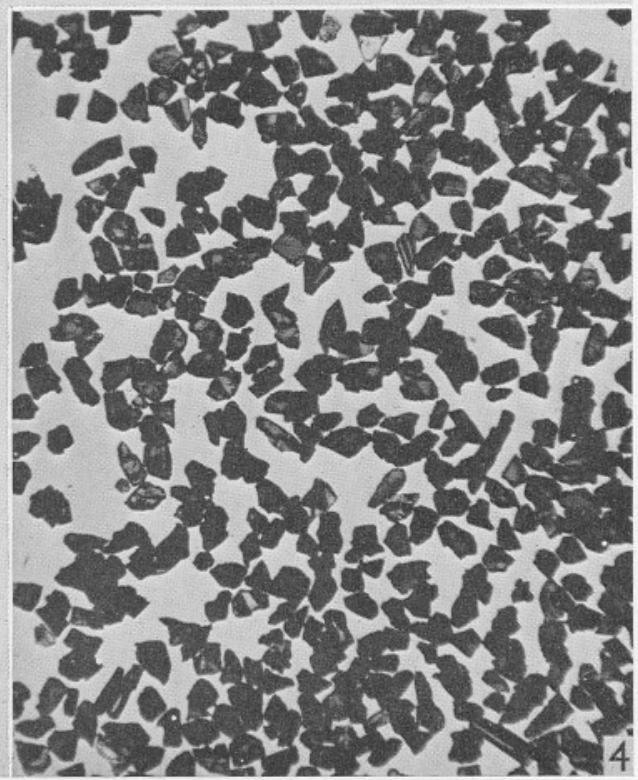
- ariber a - Th- o o o

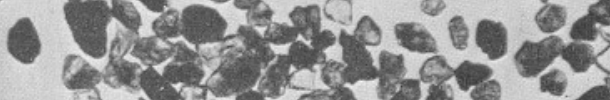
- a

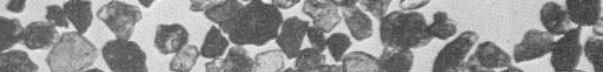

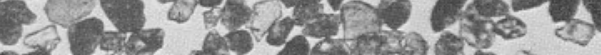

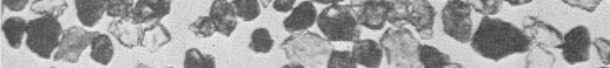

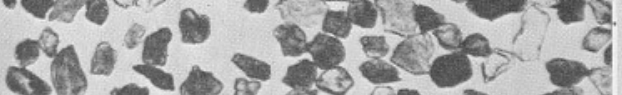
$\rightarrow 0^{2} \quad 0_{0}$ - s. 4 ar 15 per ․ $-2 \operatorname{sen}-\frac{1}{3}$

Figs. I-4. 